University of Denver

Digital Commons @ DU

Sturm College of Law: Faculty Scholarship

University of Denver Sturm College of Law

2015

High Value Lies, Ugly Truths, and the First Amendment

Alan K. Chen

Justin F. Marceau

Follow this and additional works at: https://digitalcommons.du.edu/law_facpub

Part of the Law Commons

Recommended Citation

69 Vand. L. Rev. 1435 (2015)

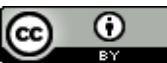

This work is licensed under a Creative Commons Attribution 4.0 License.

This Paper is brought to you for free and open access by the University of Denver Sturm College of Law at Digital Commons @ DU. It has been accepted for inclusion in Sturm College of Law: Faculty Scholarship by an authorized administrator of Digital Commons @ DU. For more information, please contact jennifer.cox@du.edu,digcommons@du.edu. 


\section{High Value Lies, Ugly Truths, and the First Amendment}

\section{Publication Statement}

Copyright held by the author. User is responsible for all copyright compliance. 


\title{
HIGH VALUE LIES, UGLY TRUTHS, AND THE FIRST AMENDMENT $\odot$
}

\author{
Alan K. Chen ${ }^{*}$ \& Justin Marceau**
}

I. INTRODUCTION

II. Constitutional Doctrine: The Treatment of Lies

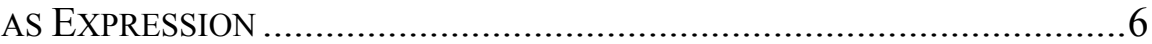

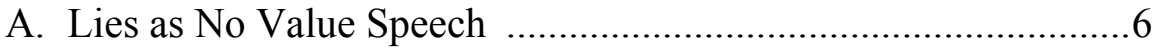

B. Lies That May Be Prohibited Because

of a Strong Government Interest ...............................................9

C. Lies That Are Protected In Order to Avoid

Chilling (as Opposed to Generating)

Truthful Speech ................................................................... 12

D. The Beginning of a New Era: United States v. Alvarez and Protecting Lies That Serve No Public Value

III. A History of High VAlue Lies - InVestigative DeCePtions ....18
A. Upton Sinclair and Lies....
.20
B. Undercover Journalism and Lies..........................................22
C. Law Enforcement and Lies ....................................................25
D. Civil Rights Testing and Lies ..............................................27
E. Animal Rights Investigators, Lying, and Ag Gag Laws ...........29

IV. SPEECH THEORY AND THE FIRST AMENDMENT

VALUE OF INVESTIGATIVE DECEPTIONS

A. Investigative Deceptions Promote Democratic

Self-Governance

B. Investigative Deceptions Promote the Broader

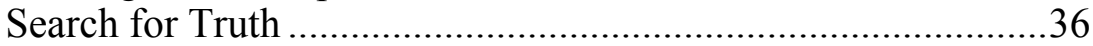

C. Investigative Deceptions Promote Individual

Autonomy

V. DOCTRINAL IMPLEMENTATION OF FiRST AMENDMENT Protection Of High VALUe LiEs.

* William M. Beaney Memorial Research Chair and Professor of Law, University of Denver Sturm College of Law.

** Associate Professor, University of Denver Sturm College of Law. The authors would like to thank participants at the 2014 Loyola University Chicago Constitutional Law Colloquium as well as our colleagues at the University of Denver Sturm College of Law who commented on earlier versions of this paper. All errors and omissions are ours alone. 
A. Considering and Applying the Proper Level of Scrutiny for Laws Criminalizing Investigative Deceptions.

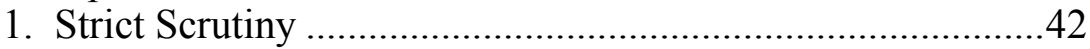

a. Reading the Alvarez Plurality Tea Leaves ....................42

b. Restrictions on High Value Lies Warrant Strict Scrutiny

c. Strict Scrutiny Under Standard First Amendment Doctrine. 45

d. Strict Scrutiny under R.A.V. v. City of St. Paul..............47

2. Intermediate Scrutiny - High Value Lies as

a Hybrid Speech Category ....

B. Limiting Principles - Cognizable Harm as a

Precondition to Criminalizing Lies ........................................53

1. Possible Direct Harms..........................................................54

a. Trespass ...................................................................55

b. Interference with Business Operations and Hiring Practices ...................................................56

c. Privacy and Autonomy...............................................60

2. Possible Indirect Harms Caused By Public Disclosure .......61

VI. CONCLUSION .66

\section{INTRODUCTION}

Lying has a complicated relationship with the First Amendment. It is beyond question that some lies - such as perjury or pretending to be a police officer - are not covered by the Constitution's free speech clause. ${ }^{1}$ But it is equally clear that some lies, even intentionally lying about military honors, are entitled to First Amendment protection. ${ }^{2}$ To date, however, it has largely been taken for granted in Supreme Court doctrine and academic writing that any constitutional protection for lies is purely prophylactic - it provides protection to the truth-speaker by also

\footnotetext{
${ }^{1}$ United States v. Alvarez, 132 S. Ct. 2537, 2546 (2012). See also United States v. Chappell, 691 F.3d 388, 400 (4th Cir. 2012). There is an important difference between what speech is covered by the First Amendment and what speech is protected. As Professor Schauer has observed, the question of First Amendment coverage is all too often "simply assumed." Frederick Schauer, The Boundaries of the First Amendment: A Preliminary Exploration of Constitutional Salience, 117 HARV. L. REV. 1765, 1767 (2004).

2 Alvarez, 132 S. Ct. at 2551; see also New York Times Co. v. Sullivan, 376 U.S. 254 (1964) (finding false speech that injures reputation is protected by the First Amendment).
} 
protecting the liar. ${ }^{3}$ What remains unresolved is whether other rationales might also justify First Amendment protection for lies.

This Article argues that some lies - what we call high value lies have intrinsic or instrumental value to the goals underlying freedom of speech. It develops a trifurcated doctrinal taxonomy of constitutional protection for lies. Some misrepresentations receive no protection at all; ${ }^{4}$ some false statements are protected only because the protection of the liar ensures that the speech of the truthful person is not indirectly chilled, ${ }^{5}$ and, in our view, some lies must be protected for their own sake. This framework is descriptively novel and doctrinally important because we provide the first comprehensive look at the wide range of lies that may raise First Amendment issues in the wake of United States v. Alvarez, ${ }^{6}$ and analyze the proper level constitutional scrutiny owed to regulations of each type of lie.

Beyond doctrine, we advance the thesis that constitutional protection for high value lies is firmly rooted in First Amendment theory because false speech sometimes paradoxically facilitates or produces truth. High value lies, though unacknowledged in the literature and cases to date, have played an important role in American history, and affirmatively further the free speech goals of enhancing political discourse, revealing of truth, and promoting individual autonomy. ${ }^{7}$ A prototypical category of high value lies is what we label "investigative deceptions." An investigative deception is the sort of misrepresentation required in order

\footnotetext{
${ }^{3}$ Just as the application of the exclusionary rule for Fourth Amendment violations results in the suppression of valuable evidence on the justification that its exclusion is necessary to protect the innocent from police overreaching, and not because of the inherent benefits for criminals, see, e.g., United States v. Leon, 468 U.S. 897, 906 (1984); Herring v. United States, 555 U.S. 135, 141 (2009), so too the protection of lies has been justified as necessary to the protection of the nonliar. The Court has expressed ambivalence about both the exclusionary rule and constitutional protection for lies, but tends to reluctantly recognize carefully tailored application of the protections as a necessary evil.

4 See, e.g., 18 U.S.C. $§ 912$ (2014) (upheld in United States v. Tomsha-Miguel, 766 F.3d 1041, 1048-49 (9th Cir. 2014)).

5 See Phila. Newspapers, Inc. v. Hepps, 475 U.S. 767, 776-77 (1986).

6132 S. Ct. 2537 (2012).

7 There are only two previous scholarly treatments of this issue of which we are aware. Jonathan D. Varat, Deception and the First Amendment: A Central, Complex, and Somewhat Curious Relationship, 53 UCLA L. REV. 1107 (2006); Helen Norton, Lies and the Constitution, 2012 S. CT. Rev. 161. In examining lies more generally, Professor Varat's insightful article includes a subsection on "Lies Designed to Procure the Truth," which sets out some of the challenges that we address comprehensively in this Article. 53 UCLA L. REV. at 1122-26. In trying to predict the implications of the Court's decision in Alvarez, Professor Norton acknowledges that "[s]ome lies have instrumental or even moral value," 2012 S. CT. REV. at 164, though she does not emphasize the types of investigative deceptions on which our work focuses. For an argument that lying may sometimes be protected speech on moral grounds, see R. George Wright, Lying and Freedom of Speech, 2011 UTAH L. REV. 1131, 1157-58 (2011).
} 
for an undercover journalist, investigator, or political activist to gain access to information or images of great political significance that would not be available if the person disclosed her media affiliations or political objectives. Investigative deceptions are affirmative misrepresentations or omissions about one's political or journalistic affiliations, educational backgrounds, or research, reporting, or political motives to facilitate gaining access to truthful information on matters of substantial public concern. ${ }^{8}$

We develop our claim by examining the confluence of two contemporary developments concerning the law of free speech - the Supreme Court's decision in Alvarez and the emergence of new laws aimed at restricting undercover investigations or whistleblowing, particularly the so-called "Ag Gag" laws. ${ }^{9}$ Ag Gag laws provide a timely and straightforward case study of the First Amendment's role in protecting high value lies because a key component of these laws is the criminalization of misrepresentations made in order to gain access to agricultural facilities. ${ }^{10}$ Under these laws, lies used to facilitate

\footnotetext{
8 Animal Legal Def. Fund v. Otter, No. 1:14-cv-00104-BLW, 2014 WL 4388158, at*2 (D. Idaho Sep. 4, 2014).

9 The term "Ag Gag" was coined by food writer Mark Bittman. Mark Bittman, Op-Ed., Who Protects the Animals?, N.Y. Times, Apr. 27, 2011, A27. As we discuss below, Ag Gag laws seek to stifle or gag whistleblowing and reporting regarding practices at commercial agricultural facilities. Several articles have addressed the First Amendment implications of Ag Gag laws from a doctrinal perspective, but none have situated the discussion against the background of First Amendment theory. See, e.g., Lewis Bollard, Ag-Gag: The Unconstitutionality of Laws Restricting Undercover Investigations on Farms, 42 EnVTL. L. ReP. NEWS \& ANALYSIS 10960 (2012); Larissa U. Liebmann, Fraud and First Amendment Protections of False Speech: How United States v. Alvarez Impacts Constitutional Challenges to Ag-Gag Laws, 31 PACE ENVTL. L. REV. 566 (2014).

10 Since 2012, more than 25 such bills have been introduced. See Ag-Gag Bills at the State Level, AM. SOC'Y FOR THE PREVENTION OF CRUELTy to ANIMALS, http://www.aspca.org/fightcruelty/advocacy-center/ag-gag-whistleblower-suppression-legislation/ag-gag-bills-state-level (last visited Feb. 22, 2015); Elizabeth Barclay, 2013 Was The Year Bills To Criminalize Animal Cruelty Videos Failed, NPR (Dec. 27, 2013, 10:39AM), http://www.npr.org/blogs/thesalt/2013/12/19/255549796/2013-was-the-year-every-new-ag-gagbill-failed; Ariel Garlow, Why Factory Farms Are Afraid of Us Looking in, ONE GREEN PLANET (June 24, 2014), http:/www.onegreenplanet.org/animalsandnature/why-the-factory-farms-areafraid-of-us-looking-in/.
} 
information-gathering for a news story, ${ }^{11}$ an academic book, ${ }^{12}$ or political mobilization $^{13}$ are all criminalized. ${ }^{14}$

At least since Upton Sinclair lied to gain critical access to the meatpacking industry to gather information for his novel, THE JUNGLE, investigators have been misrepresenting their identities and motives to expose unlawful and unethical behavior to the light of day. ${ }^{15}$ This Article is the first to consider the relationship between these high value lies and the First Amendment. It proceeds in four parts. In Part II, we explore the current jurisprudence and scholarship about lying under the First Amendment. Here, we trace the development of the law from earlier understandings that seemed to categorically exclude lying from First Amendment coverage, to a contemporary, post-Alvarez, binary understanding of free speech theory - some lies are protected and others are not. In Part III, we explore the interaction of the practical realities of lying - a complex and varied social phenomena - and the theoretical underpinnings of the First Amendment. We demonstrate that investigative deceptions are valuable as a historical and political matter and that they ought not to be relegated to the status of valueless speech. Next, in Part IV, we argue that these lies affirmatively serve the purposes of free speech - they promote democratic self-governance, enhance the search for broader truths, and facilitate speakers' autonomy and selfdetermination. Finally, in Part V, we build on this to show how Ag Gag laws and other government regulations of lying as part of undercover investigations ought to be evaluated within the framework of existing First Amendment doctrine. In short, we introduce, define and distinguish, and provide a doctrinal framework for understanding high value lies under the First Amendment.

11 See, e.g., HARPER's MAgAzINE, Ted Conover Goes Undercover as a USDA Meat Inspector, THE HARPER's BLOG (Apr. 15, 2013 2:37 AM), http://harpers.org/blog/2013/04/tedconover-goes-undercover-as-a-usda-meat-inspector/.

12 See, e.g., Timothy Pachirat, Every Twelve SeCOnds: Industrialized SLAUghter AND THE POLITICS OF Sight 15-17 (2011).

13 See, e.g., Nat'l Meat Ass'n v. Harris, 132 S. Ct. 965, 969-70 (2012) (undercover video exposing animal abuse in slaughterhouse prompted change in statute governing treatment of animals).

14 See, e.g., IDAHO CODE ANN. §18-7042(1)(a) (2014). Many Ag Gag laws also criminalize the act of recording itself, which raises equally important First Amendment concerns. In a future article, we plan to examine more specifically the concept of image capture as speech. For a general treatment of this topic, see Seth F. Kreimer, Pervasive Image Capture and the First Amendment: Memory, Discourse, and the Right to Record, 159 U. PA. L. REV. 335, 370-74 (2011).

15 See infra notes 106-113 and accompanying text. 


\section{CONSTItUTIOnAl Doctrine: The TREATMEnT OF LiES AS EXPRESSION}

As far back as the early twentieth century, the Court articulated a principle of free speech familiar to most laypeople - you can't falsely shout fire in a crowded theater. ${ }^{16}$ This common platitude embodies two underlying premises supporting the claim that false factual statements are not protected by the First Amendment - (1) they have no value (false factual statements do not promote democracy, do not, by definition, advance the search for truth, and contribute little if anything to the speaker's autonomy); and (2) they cause tangible social harm (unnecessarily alarming people will cause panic, leading to physical injuries). ${ }^{17}$

But in law, as in life, not all lies are alike. Accordingly, in examining whether some lies ought to receive First Amendment protection, it is important to understand precisely why the Court has tolerated laws that regulate false speech and to distinguish among the types of false statements - do lies have value, and what is the harm to society caused by lies?

\section{A. Lies as No Value Speech}

Free speech doctrine under the First Amendment has long been understood to follow the so-called two level speech theory. Under this approach, speech that is considered to have "high value" is entitled to robust, though not unlimited, First Amendment protection. Under much free speech theory, the value of a type of expression is measured in a utilitarian sense by determining that expression's contribution to the functions the First Amendment is said to advance - promotion of democratic self-governance, ${ }^{18}$ facilitating the broader search for truth (beyond the political realm), ${ }^{19}$ and enhancing the speaker's self-

\footnotetext{
16 Schenck v. United States, 249 U.S. 47, 52 (1919).

17 Although two level speech theory focuses primarily on the value of expression, the Court also tends to examine the social harms associated with a category of speech when determining whether it is covered by the First Amendment. For categories of expression deemed unprotected, the Court's normal mistrust of government justifications is set aside, not only because these types of speech have no or little value but also because the states' interests are not speculative, but tangible and easily understood. Thus, fighting words may have no value, but they also arguably may provoke immediate physical violence. Obscenity is said not to facilitate any traditional speech value, but also may undermine societal morals and cause harm to women. And so forth.

18 See Alexander Meiklejohn, Free Speech and Its Relation to Self-Government 75 (1948); Robert H. Bork, Neutral Principles and Some First Amendment Problems, 47 IND. L.J. 1, 26 (1971).

19 See John Stuart Mill, On Liberty (1859).
} 
realization and autonomy. ${ }^{20}$ High value speech is subject to the most stringent constitutional protection, and typically cannot be regulated on the basis of the speaker's viewpoint or the content of her expression. ${ }^{21}$

In contrast, on a more or less case-by-case basis, the Supreme Court has determined that some categories of speech fall entirely outside the First Amendment's coverage. ${ }^{22}$ The second tier of speech is made up of essentially unprotected expressive activities. Absent another constitutional limitation, the government may not only regulate speech that falls outside of the free speech clause, but also can ban it altogether. While the two level theory of speech has been incisively criticized for decades,${ }^{23}$ the Supreme Court at least formally clings to the approach as part of its doctrinal implementation of the First Amendment. ${ }^{24}$

The longest standing expression of the two level theory comes from the often quoted dictum in the Court's fighting words case, Chaplinsky v. New Hampshire. ${ }^{25}$ There, in declaring that speech rights under the First Amendment are not absolute, the Court listed several categories of speech that fall beyond its coverage. "There are certain well-defined and narrowly limited classes of speech, the prevention and punishment of which has never been thought to raise any Constitutional problem. These include the lewd and obscene, the profane, the libelous, and the insulting or 'fighting' words." 26 In addition to the implied historical pedigree ${ }^{27}$ of

20 See Martin H. Redish, The Value of Free Speech, 130 U. PA. L. REv. 591, 593 (1982); Thomas Scanlon, A Theory of Freedom of Expression, 1 PHIL. \& PUB. AfF. 204, 217-18 (1972) [hereinafter, Scanlon, Theory]. Other theorists argue that such constructivist or consequentialist approaches are not helpful to understanding free speech. See, e.g., LARRY ALEXANDER, Is THERE A Right OF FREEDOM OF EXPRESSION? 131 (2005); Andrew Koppelman, Veil of Ignorance: Tunnel Constructivism in Free Speech Theory, 107 Nw. U. L. REV. 647, 690-91 (2013).

21 Turner Broad. Sys., Inc. v. FCC, 512 U.S. 622, 641-42 (1994).

22 See United States v. Stevens, 559 U.S. 460, 468 (2010) (describing the categories of unprotected speech).

23 See, e.g., Larry Alexander, Low Value Speech, 83 Nw. U. L. Rev. 547 (1989); Harry Kalven, Jr., The Metaphysics of the Law of Obscenity, 1960 SuP. CT. REV. 1, 10-12 (1960).

24 Stevens, 559 U.S. at 468 ("From 1791 to the present, however, the First Amendment has permitted restrictions upon the content of speech in a few limited areas, and has never included a freedom to disregard these traditional limitations. These historic and traditional categories long familiar to the bar.") (citations omitted) (internal quotation marks omitted).

25315 U.S. 568 (1942).

${ }^{26}$ Id. at 571-72 (emphasis added).

27 In a forthcoming article, Genevieve Lakier discredits this historical narrative and demonstrates through her research that neither the Supreme Court nor other federal or state courts in the period prior to the New Deal routinely recognized categories of low value speech. Genevieve Lakier, The Invention of Low-Value Speech, (manuscript at 8-11) available at SSRN: http://papers.ssrn.com/sol3/papers.cfm?abstract id=2498741 (forthcoming, 128 HARV. L. REV.

). Indeed, there was both more and less First Amendment protection for categories of speech that the modern Court deems as having no or little value. On one hand, prior restraints were 
these categories of unprotected speech, the Court articulated a functional rationale for their exclusion from the First Amendment. "It has been well observed that such utterances are no essential part of any exposition of ideas, and are of such slight social value as a step to truth that any benefit that may be derived from them is clearly outweighed by the social interest in order and morality." 28 Simply put, under the two level theory, some types of speech have little or no value and therefore receive no protection.

Among the categories of unprotected, or only partially protected, expression are several types of speech that involve false statements of fact, or more bluntly, lies and misrepresentations. The Supreme Court has long suggested that "there is no such thing as a false idea," 29 premised on the notion that truth is optimally derived from free and open discourse, including the rebuttal and challenge of even the most outrageous or "false" ideas or beliefs. ${ }^{30}$ Untruthful statements of fact are another matter, because they are said to neither advance public discourse nor promote individual self-realization.

For decades, then, it was assumed that false factual statements are of no value to public discourse and thus fell entirely outside of the First Amendment's protections. The Court was unequivocal on this point. For example, it repeatedly observed that "there is no constitutional value in false statements of fact." 31 Similarly, it declared that "[n]either lies nor false communications serve the ends of the First Amendment, and no one suggests their desirability or further proliferation." 32 In equally clear language, the Court confirmed that "the knowingly false statement and the false statement made with reckless disregard of the truth, do not enjoy constitutional protection." 33 Through these repeated and definitive holdings, it became axiomatic that lying is "no value" speech and is therefore not covered by the First Amendment.

But these claims themselves were never closely examined and were probably never completely true. Lies have been painted with too broad a brush. They are assumed to lack value, but little or no effort has been spent trying to differentiate among types of lies. The remainder of this section takes up this task of creating a taxonomy of lies, and explores

presumptively invalid for all categories of speech. Id. at 27-29. On the other hand, criminal penalties on both high and low value speech were tolerated much more than they are today. Id.

28 Chaplinsky, 315 U.S. at 572 (emphasis added).

29 Gertz v. Robert Welch, Inc., 418 U.S. 323, 339 (1974).

30 Id. at 339-40 ("However pernicious an opinion may seem, we depend for its correction not on the conscience of judges and juries but on the competition of other ideas.").

31 Id. at 340.

32 St. Amant v. Thompson, 390 U.S. 727, 732 (1968).

33 Garrison v. Louisiana, 379 U.S. 64, 75 (1964); see also Time, Inc. v. Hill, 385 U.S. 374, 389 (1967) ("the constitutional [speech] guarantees can tolerate sanctions against calculated falsehoods without significant impairment of their essential function.”) (emphasis added). 
whether differences among lies ought to lead to a distinction in the degree of constitutional protection to which they are afforded.

\section{B. Lies That May Be Prohibited Because of a Strong Government Interest}

The two level theory of speech has substantially evolved in the 73 years since Chaplinsky. Some of the categories of no value speech the Court listed no longer count among the realm of the unprotected. ${ }^{34}$ The fighting words doctrine itself has been withered by criticism and narrowed almost beyond recognition. ${ }^{35}$ But the central premise of the two level theory is still intact - some types of speech have no value under the First Amendment and may therefore be banned by the government. Indeed, since Chaplinsky, the Court has expanded the list of categories of unprotected speech to include true threats, ${ }^{36}$ child pornography, ${ }^{37}$ and expression that violates copyright laws. ${ }^{38}$

Several different categories of lies also have been held to, or are assumed to, fall outside the First Amendment's protection because they lack any social value and also cause tangible harms to third parties or to society at large. Common law and statutory fraud provisions, which regulate fraudulent speech designed to induce listeners to give money to the speaker under false pretenses, are well-accepted examples of speech the government may regulate without much constitutional limitation. ${ }^{39}$ In

\footnotetext{
34 See, e.g., Cohen v. California, 403 U.S. 15, 26 (1971) (striking down conviction for lewd and profane language).

35 See Geofrey R. Stone et Al., Constitutional Law 1089 ( $6^{\text {th }}$ ed. 2009) ("The Court has not upheld a conviction on the basis of the fighting words doctrine since Chaplinsky. It has been argued that the Court's post-Chaplinsky decisions have so narrowed the doctrine as to render it meaningless, and that the doctrine is "nothing more than a quaint remnant of an earlier morality that has no place in a democratic society dedicated to the principle of free expression." (citing Stephen W. Gard, Fighting Words as Free Speech, 58 WASH U. L.Q. 531, 536 (1980).). Moreover, the Court has managed to squeeze a third level into its historically binary model of speech, with certain categories of speech, such as incitement to unlawful activity, Hess v. Indiana, 414 U.S. 105, 108-09 (1973); Brandenburg v. Ohio, 395 U.S. 444, 447 (1969), non-obscene pornography, Young v. Am. Mini Theatres, Inc., 427 U.S. 50, 70 (1976), and commercial speech, Cent. Hudson Gas \& Elec. Corp. v. Pub. Serv. Comm'n of New York, 447 U.S. 557, 562-63 (1980), deemed to be entitled to some, but not full, constitutional protection.

36 See Watts v. United States, 394 U.S. 705, 707 (1969).

37 See New York v. Ferber, 458 U.S. 747, 764 (1982).

38 See Harper \& Row Publishers. v. Nation Enters., 471 U.S. 539, 559-60 (1977).

39 Other types of fraudulent inducement unrelated to financial gain may also fall outside the free speech clause. For example, in Gilbert v. Minnesota, 254 U.S. 325, 333 (1920), the Court rejected a First Amendment claim by a person charged with discouraging military enlistment in part because his statements were deliberate misrepresentations.
} 
Illinois ex rel. Madigan v. Telemarketing Associates, Inc., ${ }^{40}$ the Court rejected a First Amendment challenge by a professional charitable fundraising organization that was sued by the state for making false and misleading misrepresentations to donors. ${ }^{41}$ In doing so, it made it clear that "the First Amendment does not shield fraud."42 Fraudulent speech bears no First Amendment value and also causes harm to those who are defrauded. ${ }^{43}$

Similarly, the government has unquestioned power to regulate false statements of fact in the context of perjury. It borders on absurd to argue that a person's lies under oath would advance any First Amendment values, since such speech obscures, rather than leads to, truth finding. Indeed, judicial proceedings are designed to smoke out the truth and resolve disputes; lies that distort or disable the judicial process are assumed to be harmful to these goals beyond any doubt. ${ }^{44}$ Perjured testimony can lead to harm to third parties (say, a wrongfully convicted criminal defendant), to the justice system itself (by undermining its ability to accurately resolve disputes), and in some cases may materially benefit the speaker (by evading liability or justice). ${ }^{45}$ Not surprisingly, then, the Court has repeatedly classified perjury as speech beyond the First Amendment's protection. ${ }^{46}$ The same could be said for laws that prohibit or criminalize making false statements to government officials in the course of their official duties. ${ }^{47}$

40538 U.S. $600(2003)$.

41 Id. at 624.

42 Id. at 612 . Although fraud is generally not covered by the First Amendment, government regulations directed at fraud are not immune from scrutiny. The Court has, for example, frowned upon broad, prior restraints aimed at preventing fraudulent speech, Schneider v. New Jersey, 308 U.S. 147, 164 (1939), and has also invalidated prophylactic measures automatically categorizing certain types of charitable solicitations as fraudulent for fear of overreaching and limiting charitable solicitation as speech, Riley v. Nat'l Fed'n of the Blind of N.C., 487 U.S. 781, 800 (1988); Sec'y of State of Md. v. Munson, 467 U.S. 947, 967-68 (1984); Village of Schaumburg v. Citizens for a Better Env't, 444 U.S. 620, 636 (1980).

43 In other areas in which the government regulates fraud, there is frequently not even a discussion or consideration of First Amendment limitations because the issue is treated as selfevident. See, e.g., Michael R. Siebecker, Corporate Speech, Securities Regulation, and an Institutional Approach to the First Amendment, 48 WM. \& MARY L. REV. 613, 641-42 (2006) (observing the many ways in which securities regulations affect speech yet are assumed to fall outside of First Amendment scrutiny). See generally Schauer, supra note 1, at 1767 ("whether the First Amendment shows up at all is rarely addressed, and the answer is too often simply assumed.").

44 United States v. Alvarez, 132 S. Ct. 2537, 2546 (2012) ("Perjured testimony "is at war with justice" because it can cause a court to render a "judgment not resting on truth."”) (citation omitted).

45 Id. at 2546.

46 See, e.g., Konigsberg v. State Bar of Cal., 366 U.S. 36, 49 n.10 (1961).

47 Alvarez, 132 S. Ct. at 2546. 
Other forms of misrepresentation that threaten the good standing and appearance of government processes also fall outside of the First Amendment, even when the misrepresentation is not made under oath. For instance, when a private citizen falsely represents that he or she is a police officer or other government official, that statement is not protected speech. ${ }^{48}$ Like the preceding examples, this type of speech has the effect not of advancing democracy or facilitating the search for truth, but of interfering with these functions. Speakers who engage in this conduct risk undermining the integrity of government processes and potentially misrepresenting or misappropriating the position and power of the state. ${ }^{49}$ As the Court has explained, statutes criminalizing the impersonation of public officials serve to avoid tangible harm to "the general good repute and dignity of the (government) service itself." 50 There is simply something different about pretending to be an agent of the government. These lies always present a risk of injury to the public reputation of the office or institution in question. ${ }^{51}$ In addition, because government actors have the imprimatur of official authority, misrepresenting oneself as having such authority presents special dangers to third parties, who believe they are dealing with, and may succumb to, one who has the backing and authority of the State. ${ }^{52}$ It is for this very reason that in civil rights litigation, actions under the color of state authority are considered to pose a particular threat to individual liberty. ${ }^{53}$ Consistent with the current law, we believe that impersonating a public official is a unique category of lying that, even when done in an investigative context, falls outside the First Amendment's scope.

Still another category of deception that is generally exempted from First Amendment protection is commercial speech. ${ }^{54}$ At one time, the

48 See United States v. Swisher, 711 F.3d 514, 522-23 (9th Cir. 2014); United States v. Tomsha-Miguel, 766 F.3d 1041, 1048 (9th Cir. 2014); United States v. Chappell, 691 F.3d 388, 392 (4th Cir. 2012).

49 Alvarez, 132 S. Ct. at 2546. See also Norton, supra note 7, at 198 (observing that lying about being a law enforcement officer harms 'the public's trust in, and thus the effectiveness of, law enforcement.").

${ }^{50}$ United States v. Lepowitch, 318 U.S. 702, 704 (1943).

${ }^{51} \mathrm{Id}$.

52 Norton, supra note 7, at 198.

${ }^{53}$ Monroe v. Pape, 365 U.S. 167, 180 (1961), overruled on other grounds by Monell v. Dep't of Soc. Servs., 436 U.S. 658, 690 (1978). See generally Alan K. Chen, Rosy Pictures and Renegade Officials: The Slow Death of Monroe v. Pape, 78 UMKC L. REV. 889, 918 (2010) (arguing that Monroe "allowed suits against officials who violate constitutional rights while clothed, sometimes quite literally, in judicial robes or police uniforms, giving them the imprimatur of the state's power.").

54 Commercial speech is "expression that is related solely to the economic interests of the speaker and its audience.” Cent. Hudson Gas \& Elec. Corp. v. Pub. Serv. Comm'n of New York, 447 U.S. 557, 561 (1980); see also Va. State Bd. of Pharmacy v. Va. Citizens Consumer Council, 
Court categorically excluded commercial speech from First Amendment coverage. $^{55}$ More recently, the Court has recognized that commercial speech may have substantial value because it advances the economic interests of the speaker and provides important information to consumers and society at large. ${ }^{56}$ But the Court has made it clear that the government has wide latitude to regulate false or misleading commercial speech. As it wrote in Central Hudson, "there can be no constitutional objection to the suppression of commercial messages that do not accurately inform the public about lawful activity. The government may ban forms of communication more likely to deceive the public than to inform it." ${ }^{, 57}$ As with the preceding categories of lies that are beyond the scope of constitutional protection, false or misleading commercial speech is not valuable to the ends served by the First Amendment and also has the potential to cause harm to those who are misled by it. ${ }^{58}$

\section{Lies That Are Protected In Order to Avoid Chilling (as Opposed to Generating) Truthful Speech}

The Court strongly suggested in its Chaplinsky dicta that libel has no First Amendment value because defamatory statements serve no truth finding function and also cause harm to those whose reputations are damaged by them. ${ }^{59}$ Since Chaplinsky, however, the Court has developed a complicated and idiosyncratic set of First Amendment rules for evaluating state defamation laws that provides robust protection for false statements directed at public officials and public figures. ${ }^{60}$ In the seminal case of New York Times v. Sullivan, ${ }^{61}$ the Court reviewed a $\$ 500,000$ judgment on a defamation claim brought by a Montgomery, Alabama county commissioner against several civil rights activists and a major

Inc., 425 U.S. 748, 771 (1976) (distinguishing between truthful and deceptive commercial speech).

55 Valentine v. Chrestensen, 316 U.S. 52, 54 (1942), overruled by Va. Pharmacy, 501 U.S. at 755 .

56 Cent. Hudson, 447 U.S. at 562-63 (recognizing intermediate scrutiny as the proper scrutiny for content-based restrictions on commercial speech); Bose Corp. v. Consumers Union of U.S., Inc., 466 U.S. 485, 504 n.22 (1984).

57 Cent. Hudson, 447 U.S. at 563.

58 For further elaboration of categories of false factual statements that are not covered by the First Amendment, see Brief of Professors Eugene Volokh and James Weinstein as Amicus Curiae in Support of Petitioner at 3-11, United States v. Alvarez, 132 S. Ct. 2537 (2012) (No. 11-210), 2011 WL 3693418 , at*3-*11.

59315 U.S. 568, 572 (1942).

60 New York Times v. Sullivan, 376 U.S. 254, 270-71 (1965) (imposing severe limitations on libel claims brought by public officials); Curtis Publ'g Co. v. Butts, 388 U.S. 130, 155 (1967) (extending Sullivan standard to public figures).

61 New York Times, 376 U.S. at 256. 
newspaper. The newspaper had published the activists' advertisement criticizing the local police, who were ostensibly under the commissioner's direction, for engaging in conduct that was antagonistic toward civil rights demonstrators. It was undisputed that some of the factual statements contained in the ad were inaccurate. The trial judge had instructed the jury that these types of statements constituted libel per se, meaning that the plaintiff need not prove actual harm or malicious intent on the speakers' part in order to recover damages.

On appeal, the Supreme Court overturned the Alabama courts' rulings upholding the defamation verdict against the defendants. Rejecting the claim that defamatory statements are categorically unprotected by the First Amendment, the Court distinguished prior cases addressing free speech and defamation because they did not involve statements critical of public officials, observing that this dispute must be evaluated "against the background of a profound national commitment to the principle that debate on public issues should be uninhibited, robust, and wide-open, and that it may well include vehement, caustic, and sometimes unpleasantly sharp attacks on government and public officials." 62 In direct conflict with the language in Chaplinsky, the Court stated that "libel can claim no talismanic immunity from constitutional limitations." 63

In the context of criticism of government officials or heated debate on important public issues, the Court recognized that speech would sometimes be exaggerated or even contain false statements. ${ }^{64}$ It went on to observe that "erroneous statement is inevitable in free debate, and that it must be protected if the freedom of expression are to have the 'breathing space' that they "need to survive." 65 These factors directly shaped the scope of the applicable First Amendment protections.

The Court held that where defamation claims are brought by public officials against speakers who criticize their conduct, those claims may not be upheld unless the plaintiff can show that the speaker's statement was made with "actual malice," meaning that the speaker made the defamatory statement with knowledge that it was false, or with reckless disregard for its falsity. ${ }^{66}$ In addition, the Court held that in order to ensure that speech is not chilled, states must require plaintiffs to prove the defendants' state of mind by clear and convincing evidence. ${ }^{67}$ The point of imposing this high burden on public official defamation plaintiffs

\footnotetext{
${ }_{62}$ Id. at 270.

63 Id. at 269.

${ }^{64}$ Id. at 271 (citing Cantwell v. Connecticut, 310 U.S. 296, 310 (1940)).

65 Id. at 271-72.

${ }^{66}$ Id. at 279-80.

${ }^{67}$ Id. at 285-86.
} 
was not that the false statements themselves had intrinsic value, but that if critics of the government were exposed to substantial tort liability, they might rein in their rhetoric in ways that would result in self-censorship of even truthful criticisms. ${ }^{68}$ Later, in Curtis Publishing Co. v. Butts, the Court applied these same heightened protections to defendants accused of defamation against any "public figures," "nonpublic persons who "are nevertheless intimately involved in the resolution of important public questions or, by reason of their fame, shape events in areas of concern to society at large." "69

The Supreme Court has also extended the New York Times standard to so-called "false light" invasion of privacy claims under state tort law. In Time, Inc. $v$. Hill, ${ }^{70}$ the Court reviewed a tort judgment against a news magazine that had published an article and photo spread connected to the opening of a fictional play loosely based on an actual crime involving individuals who held a Pennsylvania family hostage in their home. The family complained that the magazine story represented the play as accurately depicting the actual crime when in fact the play had embellished and altered the story in significant ways. The Supreme Court invalidated the jury's verdict for the family on the ground that the First Amendment protected the freedom of speech and of the press in the publication of material about matters of public concern. ${ }^{71}$

68 Id. at 279. The Court did allow that false speech might actually play a role in public discourse to the extent that it might increase the chance that truthful counter-speech would emerge in response. Id. at 279 n.19. The Court extended the New York Times standard to criminal libel claims in Garrison v. Louisiana. 379 U.S. 64, 74 (1964).

69388 U.S. at 164 (Warren, C.J., concurring in result). The majority had characterized public figures as those who "commanded a substantial amount of independent public interest at the time of the publications." Butts, 388 U.S. at 154. The opinion for the Court articulated a slightly different standard, requiring that plaintiffs must show that the speaker engaged in "highly unreasonable conduct constituting an extreme departure from the standards of investigation and reporting ordinarily adhered to by responsible publishers." Id. at 155. A majority of the Justices, however, endorsed extending the New York Times standard to these cases as well, meaning that the plaintiff must show that the speaker knew that the allegedly defamatory statements were false or showed reckless disregard for their truth. Id. at 162. This standard was contained in Chief Justice Warren's opinion, but commanded the majority of the Court. See Gertz v Robert Welch, Inc., 418 U.S. 323, 336 (1974). In Gertz, however, the Court rejected extending the heightened proof standard to defamation claims brought by private persons, even when the statements related to a highly publicized incident in which the public had a great interest. Even where private citizens are involved, however, the Court said that the state may not impose liability for defamatory statements without imposing some sort of fault standard. Id. at 347. Cf. Dun \& Bradstreet, Inc. v. Greenmoss Builders, 472 U.S. 749, 760 (1985) (plurality) (holding that defamation of private person about matters of private concern was not limited by the First Amendment).

70385 U.S. 374 (1967).

71 Id. at $387-88$ (limiting liability for state invasion of privacy torts to cases where the plaintiff shows that the speech was undertaken with knowledge of its falsity or reckless disregard for its truth.). 
As in the context of defamation, the Court's limitation of state privacy torts was based not on the value of the false or inaccurate statements in the article, but on the fear that zealous enforcement of state law to police untrue statements would likely suppress a wide range of speech, including truthful speech about matters of public concern. It expressed concern that such tort liability would create a chilling effect and "saddle the press with the impossible burden of verifying to a certainty the facts associated in news articles with a person's name, picture or portrait, particularly as related to nondefamatory matter." 72

Another context in which the Court has deemed false speech to be constitutionally protected is in its assessment of the First Amendment implications of the tort of intentional infliction of emotional distress. In Hustler Magazine, Inc. v. Falwell, the Court reviewed a tort judgment against a magazine that published a parody in the form of a fake liquor advertisement implying that a nationally known, politically active minister had lost his virginity to his mother in an outhouse. ${ }^{73}$ The Court overturned a state court judgment that imposed substantial civil liability on the magazine, holding that this type of penalty for even an "outrageous" parody of a public figure cannot withstand First Amendment scrutiny unless the plaintiff demonstrates that the there was a false statement of fact made with knowledge of the its falsity or reckless disregard for the truth of the matter. ${ }^{74}$ Recognizing a long history of parodies of public figures in political and other public discourse, the Court concluded that the threat of tort liability could create a chilling effect in the absence of a more restrictive standard. ${ }^{75}$

As these cases illustrate, the Court's broad unequivocal language that "there is no constitutional value in false statements of fact" 76 does not tell the entire story. In reality, the Court has parsed out false speech into different categories and distinguished them by their nature and context as well as by considering whether their protection might be necessary to enhance the universe of speech available to the public at large. But in each of these contexts, the Court's rationale for protecting the statements speech was to prevent the chilling of truthful speech, not because it considered the false speech to have any value.

72 Id. at 389.

73485 U.S. 46, 46 (1988).

74 Id. at 56.

75 Id. at 52-55. The Court may well have been concerned that without a higher threshold of liability, public figure plaintiffs might circumvent the New York Times rule by recasting their defamation claims as emotional distress actions.

76 Gertz. 418 U.S. at 340. 
D. The Beginning of a New Era: United States v. Alvarez and Protecting Lies That Serve No Public Value

It is safe to say that prior to 2012, the Court only allowed for First Amendment protection of false statements of fact when the dangers of government regulation of that speech outweighed any harms caused by the falsehoods. A balancing of the harm caused and the potential value of the lies was critical. However, in Alvarez, the Court struck down the Stolen Valor Act, a federal statute that makes it a crime for anyone to "falsely represent himself or herself, verbally or in writing to have been awarded any decoration or medal authorized by Congress for the Armed Forces of the United States."77 Alvarez, a local water board official, was convicted of violating the Act when he boasted during a water board meeting that he had been awarded a Congressional Medal of Honor for his military service. ${ }^{78}$ The Court invalidated Alvarez's conviction, holding that the Act violated the First Amendment right of free speech. ${ }^{79}$

The lie at issue in Alvarez is little more than a valueless act of selfpromotion and impersonation, and the government had identified a variety of harms to the military community when its honors are diluted in this way. ${ }^{80}$ Nonetheless, the Court held that such a lie was constitutionally protected. Alvarez, then, reflects a turning point: a lie of little or no value and that arguably caused some harm was nonetheless deemed protected speech.

However, the decision was a fractured one, resulting in a legal framework that remains uncertain. Justice Kennedy wrote for a four Justice plurality, which declared that false speech is not categorically unprotected by the First Amendment, and stated that strict scrutiny should be applied to the Act, which it deemed to be a content-based regulation of pure speech. ${ }^{81}$ Justice Breyer, joined by Justice Kagan, wrote an opinion concurring in the judgment, but argued that the Court ought to apply an intermediate standard of scrutiny that involved a balancing of the law's threat to free expression against the government's interest in regulating the speech. ${ }^{82}$

Underlying the reasoning of all six Justices who supported the judgment in Alvarez is the clear rejection of the proposition that lies are entitled to "no protection at all" under the First Amendment. ${ }^{83}$ In this

\footnotetext{
7718 U.S.C. $\$ 704(b)$ (2013).

78 Id. at 2542.

79 Id. at 2551.

80 Id. at 2549.

81 Id. at 2543.

${ }^{82}$ Id. at 2551 (Breyer, J., concurring in the judgment).

83 Id. at 2553.
} 
regard, there is a holding of the Court - a common denominator of reasoning ${ }^{84}$ - that some lies are protected. Equally notable, Alvarez departs somewhat from the two level theory of speech by, as noted above, recognizing that Alvarez's false statements were protected despite the fact that they lacked either intrinsic or instrumental social value. ${ }^{85}$ Both the plurality and concurring opinions regarded Alvarez's lies as nothing more than a valueless, "pathetic attempt to gain respect that eluded him," 86 yet they viewed the lie as fully protected by the First Amendment.

That is not to say that Alvarez opens the floodgates to First Amendment protection for all lies. The traditional categories of unprotected lies that we discuss above - defamation, false commercial speech, perjury, and impersonating government officials - were all acknowledged as beyond the scope of the First Amendment. ${ }^{87}$ But for the first time the Court also recognized a distinct set of lies that warranted protection, and the six Justices in the majority fundamentally agreed on the limiting principles that apply in this context. Both the plurality and concurring decisions share the view that punishing "falsity alone" is not permissible; instead the government may only regulate false speech when there is some "intent to injure" 88 or more precisely some intent to cause a "legally cognizable harm." 89 As the plurality clearly explains, "There must be a direct causal link between the restriction imposed and the injury to be prevented." 90

While there are not yet a substantial number of cases applying Alvarez, the early indications are that lower courts are taking the cue and applying broad protections to lies. For example, two lower federal courts have invalidated state laws regulating false speech in the context of political campaigns.

In 281 Care Committee v. Arneson, ${ }^{91}$ the Eighth Circuit struck down a Minnesota law making it a misdemeanor for any person to intentionally participate in "the preparation, dissemination, or broadcast of paid political advertising or campaign material ... with respect to the effect

${ }^{84}$ Justin F. Marceau, Lifting the Haze of Baze: Lethal Injection, the Eighth Amendment, and Plurality Opinions, 41 ARIZ. ST. L.J. 159, 171 (2009) (explaining that "D.C. Circuit held that a plurality decision rationale is only entitled to precedential weight if it is "implicitly approved by at least five Justices"' such that the holding reflects a common denominator of reasoning).

${ }^{85}$ Alvarez, 132 S. Ct. at 2564 (Alito, J., dissenting).

${ }^{86}$ Id. at 2542 (plurality opinion).

87 Id. at $2544-45$.

${ }^{88}$ Holloway v. Am. Media, Inc., 947 F. Supp. 2d 1252, 1263, n. 15 (N.D. Ala. 2013) ("falsity must be coupled with some other element of culpability, such as an intent to injure or defraud another person.").

${ }^{89}$ Alvarez, 132 S. Ct. a 2545.

90 Id. at 2549.

91766 F.3d 774 (8th Cir. 2014). 
of a ballot question, that is designed or tends to ... promote or defeat a ballot question, that is false, and that the person knows is false or communicates to others with reckless disregard of whether it is false." 92 While recognizing that Alvarez did not render a majority opinion defining the appropriate standard of review, the court held that the Minnesota law must be subject to strict scrutiny because it regulated politically salient speech on the basis of its content, and held that the law was unconstitutional insofar as it was not narrowly tailored..$^{93}$ Ultimately, then, as in the Supreme Court's defamation cases, the appellate court invalidated the law because of its potential to chill political speech, which often involves highly charged statements that might be deemed by opponents to be "false." 94 Similarly, in Susan B. Anthony List v. Ohio Elections Committee, ${ }^{95}$ a federal district court issued a permanent injunction preventing the state from enforcing its false campaign speech law. To a substantial degree, the court in this case used the same reasoning as the Eighth Circuit in 281 Care Committee to hold that the Ohio law violated the First Amendment. ${ }^{96}$

Cases like these illustrate the emergence of a distinct jurisprudence of lying under the First Amendment. Prior to Alvarez, it is unlikely that such statutes would have been invalidated. Of note, however, neither the false campaign speech cases nor Alvarez provide protection for the lies at issue on the ground that the lies had some intrinsic or inherent political value. Quite the contrary. As the district court in Susan B. Anthony List noted, the plaintiff, an anti-abortion advocacy group, was not asserting a "right" to lie, but a right "not to have the truth of our political statements judged by the Government." 97

\section{A History of High VAlue Lies - InVEstigative DecePtions}

Lying is a complex behavioral phenomenon. In the abstract, lying is typically viewed with almost universal moral opprobrium. But this assumes that all lies are identical; in fact, context is critical to evaluating whether lies are harmful. ${ }^{98}$ Indeed, lying in the abstract is not even

\footnotetext{
92 Id. at 778.

${ }^{93} I d$. at 784 . The court did not actually determine whether the state's interest was compelling or not. Id. at 787.

94 Id. at 793.

95 No. 1:10-cv-720, 2014 WL 4472634, at*2.

96 Id. at *13.

97 Id. at $* 1$.

98 In his opinion concurring with the Ninth Circuit's denial of rehearing en banc in Alvarez, Judge Kozinski recognized the importance of context. As he wrote,

[a]ccording to our dissenting colleagues, "non-satirical and non-theatrical[ ] knowingly false statements of fact are always unprotected" by the First Amendment.
} 
forbidden by the Ten Commandments. ${ }^{99}$ Recent studies suggest that lying is common behavior, and in many contexts lying is not only not forbidden, but also can serve socially useful functions. ${ }^{100}$ As one commentator recently reported, "We all tell lies, and tell them shockingly often: Research shows that on average in an ordinary conversation, people lie two to three times every 10 minutes."101 To be sure, many lies that society seems to tolerate are relatively trivial and socially acceptable, such as making a false statement to avoid hurting someone's feelings. ${ }^{102}$ As Justice Breyer observed in his concurring opinion in Alvarez:

False factual statements can serve useful human objectives, for example: in social contexts, where they may prevent embarrassment, protect privacy, shield a person from prejudice, provide the sick with comfort, or preserve a child's innocence; in public contexts, where they may stop a panic or otherwise preserve calm in the face of danger; and even in technical, philosophical, and scientific contexts, where (as Socrates' methods suggest) examination of a false statement (even if made deliberately to mislead) can promote a form of thought that ultimately helps realize the truth. ${ }^{103}$

Thus, it is no exaggeration to say that at least some types of lying for many purposes, perhaps even to gain employment, are socially tolerated..$^{104}$

There is also a long tradition of using deception as a means of gaining access to knowledge that would otherwise be obscured from public view. Since at least the Industrial Revolution, lies have played a central role in

. . . Not "often," not "sometimes," but always. Not "if the government has an important interest" nor "if someone's harmed" nor "if it's made in public," but always.

"Always" is a deliciously dangerous word, often eaten with a side of crow.

United States v. Alvarez, 638 F.3d 666, 673 (9 $9^{\text {th }}$ Cir. 2011) (Kozinski, J., concurring in the denial of rehearing en banc) (citations omitted).

99 Exodus 20:1-7 (King James).

100 Ulrich Boser, We're All Lying Liars: Why People Tell Lies, and Why White Lies Can Be OK, U.S. NEWS \& WORLD REPORT (May 18, 2009, 12:20 PM), http://health.usnews.com/healthnews/family-health/brain-and-behavior/articles/2009/05/18/were-all-lying-liars-why-people-telllies-and-why-white-lies-can-be-ok.

101 Clancy Martin, Op-Ed., Good Lovers Lie, N.Y. TiMES SR4 (Feb. 8, 2015).

102 Alvarez, 638 F.3d at 674 (Kozinski, J., concurring in the denial of rehearing en banc).

103 United States v. Alvarez, 132 S. Ct. 2537, 2553 (2012) (Breyer, J., concurring).

104 One recent job advice website even ran a story titled, "Why You Must Lie on Job Interviews." Mark Stevens, Why You Must Lie On Job Interviews And What You Must Lie About, LiNKEDIN (Oct. 6, 2014), https://www.linkedin.com/pulse/20141006125226-10136502-why-youmust-lie-on-job-interviews-and-what-you-must-lie-about. 
allowing the American public and the political branches of government exposure to the closed-door goings on of certain industries. From prisons, to mental hospitals, to schools, to the meatpacking industry, lies have facilitated award-winning journalism, prompted changes in public behavior, and led to major legislative reforms. Moreover, law enforcement has long engaged in investigative deceptions to gain access to private information without obtaining a warrant, and the Constitution has never stood as a barrier. ${ }^{105}$ In these and other ways, disclosure of politically salient and socially beneficial information that would have been kept secret but for investigative deceptions is critical to public discourse about important matters. This section explores the potential First Amendment values of investigative deceptions by surveying several contexts in which both law and society embrace the use of lies to investigate wrongdoing.

\section{A. Upton Sinclair and Lies}

Perhaps the most iconic example of using deception to uncover wrongdoing is Upton Sinclair's investigation of the Chicago meatpacking industry, which became the source and inspiration for his path-breaking

\footnotetext{
105 "The general rule is that government agents may use deception to gain access to homes, offices, or other places wherein illegal acts are being perpetrated. The Supreme Court has long acknowledged the use of trickery or deception to be permissible." Brokers' Choice of Am., Inc. v. NBC Universal, Inc., 757 F.3d 1125, 1146 (10th Cir. 2014). Indeed, it has been acknowledged that "if total honesty by the police were to be constitutionally required, most undercover work would be effectively thwarted." Id. (noting that ruses may take many forms but often they are used to gain access to intimate areas or details, such as one's home or one's personal secrets). See also Wayne LAFAve, ET. AL. 2 CRIM. PROC. § 3.10(c) (3d ed. 2000) (summarizing Supreme Court authority on this point as generating the "following proposition: when an individual gives consent to another to intrude into an area or activity otherwise protected by the Fourth Amendment, aware that he will thereby reveal to this other person either criminal conduct or evidence of such conduct, the consent is not vitiated merely because it would not have been given but for the nondisclosure or affirmative misrepresentation which made the consenting party unaware of the other person's identity"). But see People v. Jefferson, 43 A.D.2d 112, 113, 350 N.Y.S.2d 3 (1973) (per curiam) (finding a constitutional violation when the police lied about an emergency gas leak in the house that threatened health if not immediately inspected).

Of course, holding that the Constitution does not forbid lying is a far cry from holding that lying is constitutionally protected. But to the extent the Constitution is primarily a protection of citizens against the government, it is important to note how much deception has been permitted by the government in the name of information gathering. See Chris Hamby, Government Set Up A Fake Facebook Page In This Woman's Name, BuZzFeEd News (Oct. 6, 2014 6:16 PM), http://www.buzzfeed.com/chrishamby/government-says-federal-agents-can-impersonatewoman-online\#.favGY5 LgX (detailing a government sting based on a false Facebook page using actual photos of an arrested person in an effort to gain communication with her affiliates). It would be strange to suggest that the government has largely unchecked abilities to lie to persons to obtain deeply private information, while prohibiting private persons from engaging in limited deceptions in order to reveal non-intimate, business details of political significance.
} 
novel, THE JUNGLE. ${ }^{106}$ To gather information for his work, which he hoped would expose the many unfortunate ways in which meatpacking companies treated their employees, ${ }^{107}$ Sinclair gained access to the facilities by disguising himself as a worker. "I would wander about the yards, and my friends would risk their jobs to show me what I wanted to see. I was not much better dressed than the workers, and found that by the simple device of carrying a dinner pail I could go anywhere." 108 One of his biographers reports that the clothes and dinner pail were not quite enough, and that Sinclair gained access "armed with a few simple lies, appropriate to the area in which he was investigating." 109 Whether by commission or omission, it is clear that Sinclair gained access to the private workplaces of meatpacking plants through deception. Moreover, to protect his cover, Sinclair could not afford to be seen taking notes of his observations. Rather, he walked through the meatpacking plant, "memorizing details of what he saw, then rushing back to his room to write everything down." 110

Like modern day animal rights and labor activists, Sinclair's work was critical to exposing the unsavory practices of a wealthy and powerful industry to public scrutiny. At the time he conducted his investigation, the livestock industry was already the nation's largest and was beginning to control a bigger part of the global market. ${ }^{111}$ With all its resources, the industry was quite careful to cultivate its public image. As one Sinclair biographer observed, "The packers were wiser about public relations than most businessmen of that era, arranging Potemkin village tours to carefully manicured parts of their plants and advertising their own virtues lavishly . . .."112 Thus, it is fair to say that for more than a century undercover investigations have been critical to a politically important topic of speech that is otherwise unavailable to unscripted reporting. ${ }^{113}$

106 Upton Sinclair, The Jungle (1906). See generally Arthur Weinberg \& Lila WeINBERG, THE MuCKRAKERs 205 (2001).

107 Although THE JUNGLE would become more famous for exposing the unsanitary practices of the meatpacking industry, it is undisputed that Sinclair's primary objective, driven by his Socialist leanings, was to investigate and write about the plight of mistreated workers. LEON HARRIS, UPTON SINCLAIR: AMERICAN REBEL 70-71 (1975).

${ }^{108}$ Upton Sinclair, THE AutobiograPhy OF UPTON SinClair 109 (1962).

${ }^{109}$ HARRIS, supra note 107 , at 70 (emphasis added).

${ }^{110}$ ANTHONY ARTHUR, RADICAL INNOCENT: UPTON SinClAIR 49 (2006).

111 Id. at 45

112 HARRIS, supra note 107, at 69.

113 Sinclair was not alone in his investigative techniques. Numerous other investigative journalists of this era, including Nellie Bly, Lincoln Steffens, and Ida Tarbell, used the same methods to acquire information for their writings. See WeINBERg \& WeINBERG, supra note 118, at 431-32; see also, e.g., Nellie Bly, Ten Days in A MAD-House 5-7 (CreateSpace Indep. Publ'g Platform 2011). 


\section{B. Undercover Journalism and Lies}

Sinclair is characterized as one of the pioneers of "muckraking" journalism. ${ }^{114}$ Indeed, the history of modern journalism is filled with examples of journalists employing a wide range of devices to secure information for their stories, and passing that information on to the public. ${ }^{115}$ These efforts have ranged from simple omissions to outright lies.

One example of a journalist lying to gain access to information for a story is Ken Silverstein, who, as an editor of Harper's magazine, set out to do a story on how much Washington lobbyists promise to their foreign government clients. Silverstein represented himself as the head of the Maldon Group, supposedly a collection of private investors who were exporters of natural gas from Turkemenistan, which had a government regime that he described as "Stalinist." 116 The supposed goal of hiring a lobbying firm was to show American policymakers that the reforms being undertaken by the Turkmeni government were real, which would help increase the chance of the Maldon Group's business success. ${ }^{117}$ To support his scheme, Silverstein took what he called "minimal preparations."118

I printed up some Maldon Group business cards, giving myself the name "Kenneth Case" and giving the firm an address at a large office building in London, on Cavendish Square. I purchased a cell phone with a London number. I had a website created for The Maldon Group - just a home page with contact information - and an email account for myself. Then, in mid-February, soon after Berdymukhamedov's ascent, I began contacting various lobbying firms by email, introducing my firm and explaining that we were eager to improve relations between the "newly-elected government of Turkmenistan" and the United States. We required the services of a firm, I said, that could quickly enact a "strategic communications" plan to help us. I hoped that the firms might be

\footnotetext{
114 For a definition and origin of muckraking, see WEINBERG \& WEINBERG, supra note 118, at $\mathrm{xV}$-xvi.

115 See generally Brooke Kroeger, Undercover Reporting: The Truth About DECEPTION (2012).

116 Ken Silverstein, Their Men in Washington: undercover with D.C.'s lobbyists for hire, HARPER's BAZAAR 53, July 1, 2007, available at 2007 WLNR 26681127.

${ }^{117} \mathrm{Id}$.

${ }^{118}$ Id.
} 
willing to meet with me at the end of the month, during a trip I had planned to Washington. ${ }^{119}$

The fiction worked like a charm, and Silverstein set meetings with two powerful D.C. lobbying firms. As he described it in a later opinion essay, what he found and reported was that:

In exchange for fees of up to $\$ 1.5$ million a year, they offered to send congressional delegations to Turkmenistan and write and plant opinion pieces in newspapers under the names of academics and think-tank experts they would recruit. They even offered to set up supposedly "independent" media events in Washington that would promote Turkmenistan (the agenda and speakers would actually be determined by the lobbyists).... All this, Cassidy and APCO promised, could be done quietly and unobtrusively, because the law that regulates foreign lobbyists is so flimsy that the firms would be required to reveal little information in their public disclosure forms. ${ }^{120}$

Rather than being praised for exposing the underbelly of foreign nationals' lobbying of the U.S. government, Silverstein was taken to task by, of course, the targets of his investigation, and by other journalists for engaging in unethical behavior. As one of his most vocal critics, Washington Post reporter Howard Kurtz, wrote: "no matter how good the story, lying to get it raises as many questions about journalists as their subjects." 121

Another important illustration of the value, but also the costs, of undercover journalism is the investigation of the grocery store chain, Food Lion, conducted by two reporters from the ABC News program Primetime Live. The reporters used résumés with false identities, addresses, and references to gain employment with two different Food Lion stores. ${ }^{122}$ After they were hired, they used hidden video cameras to document and confirm what sources had initially reported to ABC News, which was that Food Lion's food handling practices were highly unsanitary and probably illegal.

\footnotetext{
${ }^{119} I d$.

${ }^{120}$ Ken Silverstein, Undercover, under fire, L.A. TIMES 29, June 30, 2007, available at 2007 WLNR 12370843.

121 Howard Kurtz, Undercover Journalism, WASH. Post, June 25, 2007, http://www.washingtonpost.com/wp-dyn/content/blog/2007/06/25/BL2007062500353.html.

122 Food Lion, Inc. v. Capital Cities/ABC, Inc., 194 F.3d 505, 510 (4 ${ }^{\text {th }}$ Cir. 1999).
} 
The broadcast included, for example, videotape that appeared to show Food Lion employees repackaging and redating fish that had passed the expiration date, grinding expired beef with fresh beef, and applying barbeque sauce to chicken past its expiration date in order to mask the smell and sell it as fresh in the gourmet food section. The program included statements by former Food Lion employees alleging even more serious mishandling of meat at Food Lion stores across several states. ${ }^{123}$

Another more subtle example of a journalist using deception to uncover an important story is Tony Horwitz, a reporter for the Wall Street Journal. Horwitz gained access to a chicken-processing plant by getting hired as an employee so that he could gather information for a story about the conditions of low wage workers. ${ }^{124}$ What Horwitz found was astonishing. The workers, who were paid extremely poorly, were given little to no training, placed in hazardous work environments subject to minimal oversight by the plant, exposed to unsanitary conditions, and subject to suspension for unexcused trips to the bathroom. ${ }^{125}$ These conditions imposed great health risks on employees. Indeed, the type of work that poultry plant workers engage in subjects them to four of the five highest risk factors for cumulative trauma: "rapid and repetitive motion, awkward postures, forceful motions, and no control over the pace of work." 126

To gain access to the plant and personally observe the working conditions, Horwitz applied for a position with a plant in Mississippi. Unlike the reporters in the prior examples, Horwitz's deception to gain access to the plant fell somewhere between an omission and an affirmative lie. When he applied for employment, he used his real name and indicated that he had a university education, but stated that his current employer was "Dow Jones \& Co.," the parent company of his actual employer. ${ }^{127}$ Horwitz, then, without telling an affirmative mistruth, concealed his identity as a newspaper reporter. Notably, however, in the early 1990s when this investigation took place, deception may not have even been necessary in order for Horowitz to gain access to the poultry plant. The industry had unusually high turnover rates, and "poultry

${ }^{123} I d$. at 511.

124 Tony Horwitz, 9 to Nowhere: These Six Growth Jobs Are Dull, Dead-End, Sometimes Dangerous - They Show How '90s Trends Can Make Work Grimmer For Unskilled Workers Blues on the Chicken Line, WALL St. J., Dec. 1, 1994, available at http://www.pulitzer.org/archives/5744.

$\begin{array}{ll}{ }_{125} \text { Id. } \\ 126 & \text { Id. } \\ 127 & \text { Id. }\end{array}$ 
companies [would] hire constantly, with few questions asked and no skills required." 128 As Horwitz reported, the plant manager barely glanced at his application before hiring him. ${ }^{129}$ For his work on this story as the centerpiece of a series about low wage workers, Horwitz was awarded the Pulitzer Prize. ${ }^{130}$

One thing is not disputed about these or the multitude of other successful undercover investigations conducted by journalists. There is no claim in any of the charges leveled against the journalists that anything they reported was untrue. As the court in the Food Lion case clearly stated, "The truth of the PrimeTime Live broadcast was not an issue in the litigation."131 Many other examples of similar investigations have been documented. ${ }^{132}$ To be sure, journalists and journalism scholars have long debated the ethics of using lies and deception in their reporting, but it is undisputed that some of these lies have led to exposure of a wide range of corruption, illegality, and other information that is indisputably of great public concern. While some defend the use of deception, and even affirmative lies, as rooted in the history of investigative journalism and as an essential tool for uncovering the hidden truth, others argue that journalists lose credibility when they engage in deception, even if that leads them to uncover valuable information. ${ }^{133}$

\section{Law Enforcement and Lies}

Another context in which lying is a predominant investigative tool is law enforcement. As with journalism, there is a vigorous debate about the morality of such practices, but there is also a very long history of lying to suspects as part of criminal investigations. The practice of deception has played a prominent role in some of the most important criminal prosecutions in U.S. history, including that of Jimmy Hoffa. ${ }^{134}$ And while the practice may attract scholarly and public criticism, courts are virtually unanimous in singing the praises of investigative deception. As the Tenth Circuit recently explained in defending the use of police deception, "if

\footnotetext{
128 Id.

129 Id.

130 Wall Street Journal reporters Horwitz and Suskind each win a Pulitzer Prize, WALL STREet J. A2 (Apr. 19, 1995).

131 Food Lion, Inc. v. Capital Cities/ABC, Inc., 194 F.3d 505, 511 (4 ${ }^{\text {th }}$ Cir. 1999).

132 See Undercover RePorting: DeCEPTION FOR JOURNALiSM's SAKE: A DATABASE, http://dlib.nyu.edu/undercover/undercover-journalism-debated (last visited Feb. 27, 2015).

133 See KroEger, supra note 115, at 3-13.

134 Hoffa v. United States, 385 U.S. 293, 303 (1966); United States v. White, 401 U.S. 745, 746-47 (1971); Sorrells v. United States, 287 U.S. 435, 441-42 (1932) (noting the importance of deception to investigations).
} 
total honesty by the police were to be constitutionally required, most undercover work would be effectively thwarted."135 Echoing similar sentiments, one commentator has observed, "As a society, we find living with the use of such deception disconcerting, yet we dare not abandon such techniques."136

It is accepted that law enforcement investigatory tactics oftentimes involve deception. Most notably, government officials routinely lie or misrepresent their identities, as well as other factual information, in undercover criminal investigations, or "stings."137 Typically, these operations involve government agents posing as criminals or other actors affiliated with criminal activity in order to investigate violations of law. Law enforcement agents go undercover to investigate crime, posing as drug dealers, prostitutes, terrorist sympathizers, and various other participants in criminal enterprises, to gather information that they would otherwise be unable to access. ${ }^{138}$

Perhaps one of the most best known examples of a government sting is the Federal Bureau of Investigation's “Abscam" investigation. ${ }^{139}$ The name Abscam was derived from Abdul Enterprises, a fake company set up by the FBI to recover stolen art and securities. ${ }^{140}$ As the investigation developed, it extended beyond its initial goals to pursue charges of bribery of public officials. ${ }^{141}$ As with other investigative tactics, government stings can cross the line from investigation to entrapment, ${ }^{142}$ but the effectiveness of legitimate undercover investigations is widely acknowledged. ${ }^{143}$

135 Brokers' Choice of Am., Inc. v. NBC Universal, Inc., 757 F.3d 1125, 1146 (10th Cir. 2014).

${ }^{136}$ Bernard W. Bell, Secrets and Lies: News Media and Law Enforcement Use of Deception As an Investigative Tool, 60 U. PITT. L. REV. 745, 746 (1999).

137 See, e.g., United States v. Hugs, 109 F.3d 1375, 1377 (9th Cir. 1997) (involving an agent "[p]osing as a semiretired contractor interested in hunting, fishing, and purchasing trophy big game heads" who brought beer, and participated in an illegal hunt in order to gain the evidence necessary for an arrest based on violations of hunting related laws). See also GARY T. MARX, UNDERCOVER: POLICE SURVEILLANCE IN AMERICA 186-87 (1988).

138 "Law enforcement officers use undercover techniques to infiltrate the mafia, enforce narcotics laws, apprehend prostitutes or 'johns,' test the integrity of public officials, and catch thieves who seek to sell stolen property." Bell, supra note 136 , at 746.

139 Katie Lannigan, FBI undercover 'stings': Catching politicians red-handed, ALJAZEERA AMERICA (October 30, 2013, 9:00 PM), http://america.aljazeera.com/articles/2013/10/30/fbiundercover-stingscatchingpoliticiansredhanded.html.

${ }^{140}$ United States v. Kelly, 707 F.2d 1460, 1461-62 (D.C. Cir. 1983).

141 Id. at 1462.

142 See Jacobson v. United States, 503 U.S. 540, 553-54 (1992).

143 See, e.g., Katherine Goldwasser, After Abscam: An Examination of Congressional Proposals to Limit Targeting Discretion in Federal Undercover Investigations, 36 EMORY L.J. 75, 78 (1987). 
The Supreme Court has approved such deceptions under an "assumption of risk" theory. ${ }^{144}$ The idea is seductively simple - in talking to other persons, or inviting them into parts of your life one always assumes the risk that the person might turn out to be a reporter, a cop, or some other form of false friend. ${ }^{145}$ One is free to choose his friends and companions, and free to choose what to share with them, but if the trusted friend or colleague turns out not to have your best interest in mind, you can't complaint that the deception caused your harm. The deceiver's morality can be debated, but the propriety of using the evidence to prevent public harm or crimes is beyond peradventure at this point. ${ }^{146}$

\section{Civil Rights Testing and Lies}

A third area in which lying routinely and effectively has been used to expose the truth about matters of public concern is federal housing discrimination law. The Fair Housing Act of 1968 ("FHA") prohibits various forms of race, sex, religion, and national origin discrimination in the sale or rental of housing. ${ }^{147}$ As with other violations of law, housing discrimination can be difficult to detect. This is particularly true of racial steering, which is conduct through which persons discourage persons from pursuing housing opportunities on a discriminatory basis. A person who represents to another person "because of race" or other protected category that "any dwelling is not available for inspection, sale, or rental when such dwelling is in fact so available" 148 violates the FHA. A critical method of identifying racial steering and enforcing the FHA has been the use of "testers" by both government officials and private civil rights organizations. In the context of housing discrimination investigations, "'testers' are individuals who, without an intent to rent or purchase a home or apartment, pose as renters or purchasers for the purpose of collecting evidence of unlawful steering practices."149 So, for example, investigators will send a white tester and an African American tester to the same person to inquire about buying or renting a home. If that person

144 See, e.g., Hoffa, 385 U.S. at 303; United States v. White 401 U.S. 745, 749 (1971); Katz v. United States, 389 U.S. 347, 352 (1967).

${ }^{145}$ In this way, the media, law enforcement, and any other deceptive person are assumed to have an equal claim to the right to deceive an individual. Bell, supra note 136, at 836 ("The Court has adopted an equal treatment approach (more commonly described as an assumption of the risk approach) in which it purports to determine citizens' 'reasonable' expectations of privacy against all possible intruders, be they law enforcement, media representatives, or others.").

146 See Hoffa, 385 U.S. at 302 (describing a wrongdoers belief or confidence in deceiver as "misplaced" and undeserving of Fourth Amendment protection).

14742 U.S.C. $\$ 3604$ (2014).

14842 U.S.C. $\$ 3604(d)$.

149 Havens Realty Corp. v. Coleman, 455 U.S. 363, 373 (1982). 
informs the white tester that housing is available, but tells the African American tester that it is not, an FHA violation has occurred. ${ }^{150}$

Simply put, testing necessarily involves lying. Testers frequently provide false names, addresses, and other identifying data. ${ }^{151}$ The testers also provide manufactured information such as credit ratings and employment information to housing sellers or landlords that conveys that, other than their race, they are essentially indistinguishable. ${ }^{152}$ Moreover, of course, the testers are all intentionally lying about their desire to buy or rent the property in question. Civil rights testing is based on social science methods that require control over every variable except race as a method of proving discrimination. ${ }^{153}$ This is especially useful under the FHA, which is violated by disparate treatment. ${ }^{154}$

Fair housing testing has been approved by the Supreme Court, which has not only recognized such testing as an established practice, but held that groups who hire persons to do these undercover investigations enjoy Article III standing to bring FHA claims in federal court. ${ }^{155}$ Congress, too, has expressly embraced testing. ${ }^{156}$ It established the Fair Housing Initiatives Program ("FHIP") as a temporary measure in 1987, and permanently in 1991. ${ }^{157}$ The FHIP authorizes the Secretary of Housing and Urban Development to allocate funds to private non-profit housing enforcement organizations to investigate violations of the FHA through testing. ${ }^{158}$ The Secretary is required to establish guidelines for such testing activity to ensure that such activity produces "credible and objective evidence of discriminatory housing practices."159 These guidelines place several limitations on who can be testers, but do not, and by definition could not, prohibit testers from engaging in deception and misrepresentation as part of their investigations. ${ }^{160}$

150 Id. at 374.

1511 EMPlOyment Discrimination LAW AND Litigation $§ 12: 6$ (2014).

152 Id.

153 Id.

154 See 42 U.S.C. $\$ 3604$.

155 Havens, 455 U.S. at 379.

156 In addition to the FHA, the False Claims Act (FCA) reflects the congressional endorsement of undercover investigations, often predicated on deception. The FCA provides for individuals who reveal frauds against the federal government to receive sizeable awards. 31 U.S.C. $\S 3730$ (2010). Notably, empirical data reveals that most of the FCA actions are brought by private investigators - that is persons who gain employment or access through deception. David Freeman Engstrom, Harnessing the Private Attorney General: Evidence from Qui Tam Litigation, 112 Colum. L. REV. 1244, 1278-80 (2012).

15742 U.S.C. $\$ 3616 \mathrm{a}(2014)$.

15842 U.S.C. $\$ 3616 \mathrm{a}(\mathrm{b})(2)(\mathrm{A})$.

15942 U.S.C. $\S 3616 a(f)(2)$.

${ }^{160}$ For example, testers under FHIP may not have prior felony convictions or convictions of any crimes involving fraud or perjury. 24 C.F.R. $\S 125.107$ (2015). 
There is evidence that testing has been effective in identifying and rooting out housing discrimination. In 1996, the Iowa Civil Rights Commission issued a report that testing as a result of FHIP grants resulted in the identification of 136 possible FHA violations and the filing of 41 complaints. ${ }^{161}$ A 1988 Urban Institute conference produced several papers that identified the effectiveness of civil rights testing. As stated in the executive summary, "[e]vidence of discrimination has come from several sources, including analysis of aggregate employment, housing, and other data sets. While the regression techniques employed in these analyses have much to offer, they fail to provide the clear, direct measures and narrative power offered by paired testing."162 While testing, through intentional lies, originated in the context of fair housing, it is now used to investigate discrimination in other contexts, and has been expanded to include, among other things, disability discrimination investigations. ${ }^{163}$

\section{E. Animal Rights Investigators, Lying, and Ag Gag Laws}

Following the path of muckrackers, investigative journalists, law enforcement officials, and civil rights testers, animal rights activists, scholars, and journalists in recent years have been conducting their own undercover investigations of the agricultural industry to expose unlawful and unethical mistreatment of animals. And they have been extraordinarily effective. In a gripping account of the modern industrial production of meat, political scientist Timothy Pachirat published a book that provides a thorough account of his undercover investigation of a Nebraska slaughterhouse. ${ }^{164}$ The book, EVERY TwELVE SECONDS, provides an insider's account of what it is like to work in a facility that kills one cow every twelve seconds, or 2,400 animals per day. ${ }^{165}$ Likewise, award winning journalist Ted Connover did an undercover investigation in 2013, and wrote a graphic article in Harper's titled The

161 See Iowa Civil Rights Commission 1996 Annual Report: Testing, available at http://publications.iowa.gov/1555/1/index.html. See also Kathryn Lodato, et al., Investigatory Testing as a Tool for Enforcing Civil Rights Statutes: Current Status and Issues for the Future, PuBLIC LAW RESEARCH InSTITUTE 5 (2004), http://gov.uchastings.edu/publiclaw/docs/plri/testing.pdf.

162 A National Report Card on Discrimination in America: The Role of Testing, (Michael Fix \& Margery Austin Turner, eds. 1998).

163 Kelly Johnson, Testers Standing Up for Title III of the ADA, 59 CASE W. RES. L. ReV. 683, 685 (2009); see also Steven G. Anderson, Tester Standing Under Title VII: A Rose by any Other Name, 41 DePAul L. ReV. 1217, 1218 (1992) (employment discrimination testers).

164 See PACHIRAT, supra note 12 , at $\mathrm{x}$.

165 Id. at 9. 
Way of the Flesh. ${ }^{166}$ These are but two examples of a body of investigative work that is of considerable political import.

Perhaps no undercover investigations in the agricultural field this century, however, have been more powerful than those produced by animal welfare organizations. In 2008, for example, the Humane Society of the United States released video footage from the Hallmark slaughterhouse in Chino, California that showed, workers "kicking cows, ramming them with the blades of a forklift, jabbing them in the eyes, applying painful electrical shocks and even torturing them with a hose and water in attempts to force sick or injured animals to walk to slaughter." 167 The footage was so powerful that it resulted in criminal charges against a slaughterhouse manager, the largest beef recall in U.S. history, a $\$ 500$ million False Claims Act judgment, ${ }^{168}$ and state legislation mandating better treatment of injured animals. ${ }^{169}$

It is hard to imagine a lie - the deceptions by the Humane Society investigator in obtaining and performing his job - that could have resulted in more positive or dramatic social and political consequences. ${ }^{170}$ To be sure not every journalistic or activist investigation of an agricultural facility has such striking or clearly traceable results. But the numerous investigations over the past couple of decades are all playing an important role in informing the modern political debate about agricultural production. These exposés have played a material role in shaping the debate about animals as food in the United States. The investigations are one of the most effective tools in convincing persons to reduce or eliminate animal products from their diet. ${ }^{171}$ Likewise, industry

166 Ted Conover, The Way of All Flesh: Undercover in an industrial slaughterhouse, HARPER'S MAGAZINE (Feb. 28, 2015), http://harpers.org/archive/2013/05/the-way-of-all-flesh/.

${ }^{167}$ Rampant Animal Cruelty at California Slaughter Plant, HuMANE SOCIETY OF THE UNITED STATES (Jan. 30 , 2008)

http://www.humanesociety.org/news/news/2008/01/undercover_investigation_013008.html.

168 Linda Chiem, Slaughterhouse Owners Hit With \$500M Judgment in FCA Case, LAw360 (Nov. 16, 2012, 9:35 PM), http://www.law360.com/articles/394827/slaughterhouse-owners-hitwith-500m-judgment-in-fca-case.

${ }^{169}$ Natl. Meat Ass'n v. Harris, 132 S. Ct. 965, 969 (2012) ("the video also prompted the California legislature to strengthen a pre-existing statute governing the treatment of nonambulatory animals"); id (nullifying the California law as preempted by federal law).

170 One commentator has observed that the greatest protection for news gathering must apply when the matters investigated are "of the most serious public concern," explain that "[s]uch matters would include felonies, corruption of public officials, dangers to our democratic institutions, and activities that imperil the public health and safety." Andrew B. Sims, Food for the Lions: Excessive Damages for Newsgathering Torts and the Limitations of Current First Amendment Doctrines, 78 B.U. L. REV. 507, 537 (1998). Agricultural investigations implicate all of these concerns.

${ }^{171}$ Most Americans who are making the switch to veganism and vegetarianism are doing so due to "how much we have learned about commercial farming and animal treatment over the last five years." http://news.therawfoodworld.com/16-million-people-us-now-vegan-vegetarian. , 
researchers have recently concluded the work of these investigative groups is emerging as the "primary source of information about livestock and poultry welfare, by consumers." 172 To the extent that the First Amendment is animated by the goals of facilitating democratic selfgovernance and the broader search for truth, these activities clearly advance those objectives.

Notably, as in other fields, there is no viable alternative to an undercover investigation. Those who are transparent about their investigative objectives are likely to be subject to the same Potemkin village effect as Sinclair confronted in his times. ${ }^{173}$ Organized farm tours and carefully chaperoned visits will not produce the sort of images or information that has become the centerpiece of the American debate on farmed animal welfare. The same barriers to investigation are likely to emerge in other areas of social interest. For example, a consensual or scheduled tour of an abusive childcare facility will not likely reveal to the reporter any abuse or neglect.

Just as Upton Sinclair's work led to federal law reforms, recent investigations have led to food recalls, state laws, and criminal prosecutions. In response to the prominence and efficacy of these investigations and their public exposure of the unsavory and sometimes unlawful practices of commercial agricultural operations, the agricultural industry has sought to enact laws that would make these investigations impossible. These so-called Ag Gag laws make undercover investigations by journalists, researchers, or investigators illegal.

Since 2012, more than 25 states have introduced Ag-Gag bills, ${ }^{174}$ and five such bills have been enacted into law. ${ }^{175} \mathrm{~A}$ critical feature of most of these laws is the criminalization of all access to agricultural sites based

172 McKendree, et. al., Effects of demographic factors and information sources on United States consumer perceptions of animal welfare, J. ANIMAL SCI. (2014).

173 See HARRIS, supra note 112, at 69.

174 The first Ag-Gag laws passed were actually passed in 1990 and 1991 in Kansas, Montana and North Dakota. However, these laws primarily targeted those who were trespassing to acquire footage at agricultural facilities and did not criminalize much if any conduct that was not already criminalized by general trespass laws. Moreover, in 2002 the ALEC drafted Animal Enterprise Terrorism Act (“AETA") was rushed through Congress without debate. WILl POTTER, GREEN IS THE New Red: An Insider's Account of A Social Movement Under Siege, 170-73 (2011). The AETA bill made it a felony to: "Enter an animal or research facility to take pictures by photograph, video camera, or other means with the intent to commit criminal activities or defame the facility or its owner." Id. at 128.

175 IDAHO CODE ANN. § 18-7042 (West 2014); UtAH CODE ANN. § 76-6-112 (West 2014); Iowa Code $\S 717$ A.3A (2015); Mo. Rev. STAT. § 578.013 (2014); S.C. Code AnN. § 47-21-50 (2014); see also Sarah R. Haag, FDA Industry Guidance Targeting Antibiotics Used in Livestock Will Not Result in Judicious Use or Reduction in Antibiotic-Resistant Bacteria, 26 ForDHAM Envtl. L. Rev. 313, 318 (2015); Sarah Evelynn, Does Ag-Gag Make You Gag?, Bill Track 50, http://www.billtrack50.com/blog/civil-rights/does-ag-gag-make-you-gag/. 
on deception, misrepresentations, or false pretenses. ${ }^{176}$ The laws tend to target gaining employment for investigative purposes specifically, and all misrepresentations to gain access more generally. ${ }^{177}$ For example, Utah's Ag Gag law criminalizes: "obtain[ing] access to an agricultural operation under false pretenses" or obtaining employment for purposes of obtaining recordings of sounds or images. ${ }^{178}$ The Idaho version makes it a crime to "enter[] an agricultural production facility by force, threat, misrepresentation or trespass;. . . [or] obtain[] employment with an agricultural production facility by force, threat, or misrepresentation with the intent to cause economic or other injury." 179

These laws go beyond generally applicable trespass laws, and instead single out those who wish to gain access to agricultural facilities. They also extend well beyond laws prohibiting fraud, invasions of privacy, or physical damage, insofar as the criminalized conduct need not produce any injury other than the exposure of illegal or otherwise abhorrent practices through an undercover recording or a written account of what was observed. In other words, Ag Gag laws criminalize lies even when they do not directly cause any injury at all, but rather expose the practices or illegal acts of a massive, federally subsidized, politically active industry. All Ag Gag laws authorize some forms of criminal punishment for violators, including prison time, fines, and restitution. ${ }^{180}$

Moreover, the legislative purpose behind these laws is much less opaque than the typical criminal statute. The legislative history, the effect of the laws, and the context, ${ }^{181}$ all evince a legislative desire to target

176 See, e.g., IDAHO CODE ANN. § 18-7042(1)(a), (c); UTAH CODE ANN. § 76-6-112(2)(b). One state, Missouri, criminalizes the failure immediately report observed abuse. This law makes long-term investigations that would show a pattern or practice of abuse and potentially implicate management criminal, and there are certainly constitutional concerns with these laws as well. For present purpose, however, we set the Missouri statute to one side because it does not apply directly to lies. Mo. Rev. STAT. § 578.013 ("Whenever any farm animal professional videotapes or otherwise makes a digital recording of what he or she believes to depict a farm animal subjected to abuse or neglect [...] such farm professional shall have a duty to submit such videotape or digital recording to a law enforcement agency within twenty-four hours of the recording").

177 IdAho Code ANN. § 18-7042(1)(a), (c); UTAH CODE ANN. § 76-6-112(2)(b), (c).

178 Utah Code Ann. § 76-6-112(2).

179 IDAHO CODE ANN. § 18-7042(a), (c). Some laws establish a separate criminal offense for the actual conduct of making a non-consensual audio or video recording on the premises of an agricultural operation. $\S 18-7042(\mathrm{~d})$. The constitutional protections applicable to image and sound capture in non-public forum raise distinct questions that we will address in a subsequent article. There are currently lawsuit challenging the constitutionality of the Utah and Idaho Ag Gag laws. The authors disclose that they serve as plaintiffs' counsel in both of these cases.

180 IdAho Code ANN. § 18-7042(3); Iowa Code $\S 717$ A.3A; 903.1; Mo. Rev. STAT. $\S$ 578.013(3); 558.011(1)(5); S.C. Code ANN. § 47-21-80; UTAH CODE ANN. § 76-6-112(3)-(4); -3204(2)-(3).

181 See Arlington Heights v. Metro. Hous. Dev. Corp., 429 U.S. 252, 267-68, 267 n.16, n.17, 268 n.18 (1977). 
animal rights activists and sympathetic journalists and subject their political speech to disfavored treatment. ${ }^{182}$ Illustrative are the comments from the executive director of the group that drafted the Idaho Ag Gag bill: "This impacts our industry. So, you have to look and say, you know, you don't stand up on a soapbox and broadcast."183 Similarly, an Idaho state representative spoke in favor of a recent Ag Gag law by explaining that "[b]y releasing the footage to the Internet, with petitions calling for a boycott of products of any company that bought meat or milk from Bettencourt Dairy, the organizations involved then crossed the ethical line for me." 184 The desire to shield an industry from public scrutiny of the most damaging kind - exposure by whistleblowers - is explicit in the legislative record.

\begin{abstract}
$* * *$
In short, deception has a long and storied, if controversial, role in American history. "[O]ur most cherished image of the press is the fearless reporter who uncovers matters we would prefer not to see or think about." 185 And while there may be instances where deception used to facilitate access to private information goes too far towards violating the privacy of an individual, many undercover investigations seek information that cannot be fairly "consider[ed] private, [such as] [t]he restaurant critic who pretends to be a regular customer, the journalist who pretends to be a taxicab fare and records his interaction with the cab driver, the housing tester who pretends to need a dwelling and records his interaction with a realtor, or even the television producer who obtains a job at a food processing plant and records food-handling practices she observes."186 As we explain in the remainder of the paper, when the information revealed through the use of deception relates to a matter of great political significance or public debate and the information revealed is not of an intimate personal nature, the deceptions used to gain such information enjoy a unique status under the First Amendment.
\end{abstract}

\footnotetext{
182 See, e.g., Bollard, supra note 9, at 10965-66.

183 Bob Naerebout, Executive Director of the Idaho Dairyman's Association, Idaho Senate Ag Committee Transcripts, Feb. 20, 2014, p. 30, lns. 9-11

184 Representative Donna Pence, Pence Legislative 2014 Update Week 7, Donna Pence Legislative Updates \& News (Feb. 21, 2014), archived at http://perma.cc/K4BB-F9GS.

185 Bell, supra note 136, at 837.

186 Id. at 750.
} 


\section{SPEECH THEORY AND THE First AMENDMENT VALUE OF INVESTIGATIVE DECEPTIONS}

Even after Alvarez, the Court has never explicitly distanced itself from the longstanding view that "[u]ntruthful speech, commercial or otherwise, has never been protected for its own sake."187 That is, it has never considered that false factual speech might in some contexts actually have either intrinsic or instrumental social value. The Court has recognized the necessity of protecting lies under the First Amendment, but it has done so only when necessary a prophylactic protection to avoid chilling truthful speech. ${ }^{188}$

This approach has considerable intuitive appeal. Deliberate misrepresentations would seem to be completely at odds with advancing democratic self-governance or the broader "truth-seeking function of the marketplace of ideas" that are often cited as central objectives of the First Amendment. ${ }^{189}$

In this Part, we offer a novel view of the intersection of the First Amendment and lying by arguing that contrary to the conventional wisdom, lies by journalists, law enforcement officers, other investigators, and political activists made for purposes of exposing illegality or other private conduct that involves matters of important public concern advance the First Amendment's values. Specifically, most contemporary free speech theory is predicated on instrumental justifications for constitutional protection of expression ${ }^{190}$ and lies of the sort we have discussed in the previous section - investigative deceptions - actually serve these values underlying the First Amendment. Stated more directly, certain lies are of affirmative value to the three primary theoretical

187 Va. State Bd. of Pharmacy v. Va. Citizens Consumer Council, Inc., 425 U.S. 748, 771 (1976) (emphasis added). See also Alvarez, 132 S. Ct. at 2545 (explaining that such a view of false speech in prior cases arose in the context of defamation or fraud or some other "legally cognizable harm associated with a false statement").

${ }^{188}$ As the Alvarez plurality explained: "Were the Court to hold that the interest in truthful discourse alone is sufficient to sustain a ban on speech, absent any evidence that the speech was used to gain a material advantage, it would give government a broad censorial power unprecedented in this Court's cases or in our constitutional tradition. The mere potential for the exercise of that power casts a chill, a chill the First Amendment cannot permit if free speech, thought, and discourse are to remain a foundation of our freedom." United States v. Alvarez, 132 S. Ct. 2537, 2548 (2012).

189 Hustler Magazine, Inc. v. Falwell, 485 U.S. 46, 52 (1988).

190 Other scholars reject these instrumentalist theories of speech and argue instead that the freedom of expression can best be understood by focusing on the government's reasons for regulation. Larry Alexander argues that "[f]reedom of expression is implicated whenever an activity is suppressed or penalized for the purpose of preventing a message from being received. ALEXANDER, supra note 21, at 9. See also Koppelman, supra note 20, at 722. 
purposes of the First Amendment: democracy, truth-facilitation, and selffulfillment. Such lies are a high value form of expression.

\section{A. Investigative Deceptions Promote Democratic Self-Governance}

One of the dominant speech theories argues that speech must be protected to ensure the advancement of democratic self-government. ${ }^{191}$ As one of its most prominent proponents has written, "The primary purpose of the First Amendment is ... that all the citizens shall, so far as possible, understand the issues which bear upon our common life."192 Meaningful deliberation about such issues can only take place with free and open discourse. More recently, Robert Post has observed that the democracy-based theory of speech requires protection of the process of forming public opinion ${ }^{193}$ On this view, the First Amendment ought to protect "those speech acts and media of communication that are socially regarded as necessary and proper means of participating in the formation of public opinion," which he calls "public discourse."194 "The function of public discourse," he writes, "is to enable persons to experience the value of self-government." 195

Both its strength and weakness as a First Amendment theory is the fact that self-governance is limited to protecting speech that is at least somewhat related to public affairs, either in the context of electoral politics or public policy debates. While some types of speech are more difficult to defend on democracy grounds, ${ }^{196}$ investigative deceptions are almost always directly linked to the advancement of self-governance. After all, as we have described, some of the most famous and award winning journalism is predicated on an investigative deception that led to access to a commercial, governmental, or other non-intimate enterprise. As the previous discussion illustrates, deception and lies can sometimes effectively uncover criminal conduct, enhance transparency in government, expose race discrimination, and reveal animal abuse, among many other types of illegal conduct. ${ }^{197}$ These are all matters of public concern and increasing public scrutiny of them undoubtedly advances

191 See sources cited infra notes 201-05.

192 MeIKLejohn, supra note 19, at 88-89.

193 Robert Post, Participatory Democracy and Free Speech, 97 VA. L. ReV. 477, 483 (2011).

194 Id.

195 Id.

196 See, e.g., Alan K. Chen, Instrumental Music and the First Amendment, 66 Hastings L.J. 381, 385 (2015).

197 See generally KROEGER, supra note 115. 
democracy in meaningful ways. ${ }^{198}$ Investigative deceptions about journalistic motives or the like actually enhance public discourse and produce information that may play a role in shaping public opinion, and thus investigative deceptions seem well anchored in the promotion of self-governance.

Accordingly, limits on such lies of access run afoul of the principle that "debate on public issues should be uninhibited and robust,"199 and, more generally, undermine the central concerns of the First Amendment. And this is no less true for investigative deceptions in the agricultural context, like the sort of misrepresentations criminalized by Ag Gag statutes. Animal welfare has become an important national public policy issue. Investigations in this field regularly result in front page stories in major newspapers, televised investigative reports, and animal welfare bills introduced and debated at the federal, state, and local level. ${ }^{200}$ The impact of Ag Gag laws in criminalizing investigative deceptions is to obscure and shield from public sight matters that are indisputably of public concern because they directly inform the public discussion and the policy debate in this vital and increasingly important issue. ${ }^{201}$ Food safety, environmental, labor, and animal welfare issues that arise in a massively subsidized industry must fall near the top of any list of politically significant issues. ${ }^{202}$

\section{B. Investigative Deceptions Promote the Broader Search for Truth}

Under another understanding, protection of speech from state interference is necessary to advance the search for "truth," which is defined as broader than political truth, but extends to a more general

198 As Dean Post has observed, "[t]he difficulty is that government control over factual truth is in tension with the value of democratic legitimation."). ROBERT C. POST, DEMOCRACY, EXPertise, ACAdEMiC FreEdom: A First Amendment JuRisPrudenCE FOR the Modern State 119 n.10 (2012).

199 Bartnicki v. Vopper, 532 U.S. 514, 534 (2001) (recognizing a "profound national commitment to the principle that debate on public issues should be uninhibited, robust and wideopen") (citing New York Times Co. v. Sullivan, 376 U.S. 254, 270 (1964)).

200 See, e.g., Michael Moss, In Quest for More Meat Profits, U.S. Lab Lets Animals Suffer, N.Y. Times, Jan. 20, 2015, at A1; Stephanie Strom \& Sabrina Tavrnise, Animal Rights Group's Video of Hens Raises Questions, but Not Just for Farms, N.Y. TIMES, Jan. 8, 2015, at B3.

201 In his scholarship on lying, Wright makes a more indirect claim that lies advance democracy. Wright, supra note 7, at 1143-44. In his hypothetical scenarios, which involve lying to fugitive slave hunters or Nazi SS officers, he suggests that lying to protect those who are being searched for might promote, among other things, liberal democracy. Id. We take him to mean this in the sense that the lies in that context undermine the terror-driven reign of a totalitarian regime rather than, as we argue, the direct contribution to information crucial to public discourse.

202 Sims, supra note 170, at 537. 
theory of social enlightenment. ${ }^{203}$ Importantly, the notion of truth under this theory emphasizes the truth of ideas, rather than factual truths. A key notion here, and one that is often drawn upon in judicial decisions about speech, is that there is no such thing as a false idea, and that truth can ultimately only emerge through robust, open discourse in the so-called marketplace of ideas. ${ }^{204}$

In the context of undercover agricultural investigations, even beyond the legal and public policy questions that are placed into issue when exposés of the agricultural industry are conducted, there are significant moral and philosophical questions relevant to the First Amendment search for truth that are also informed by this information. To take but one easy example, while some might believe that agricultural animals are merely unfeeling, unthinking forms of property, like tractors or barns, many others believe that any use or exploitation of animals for human gain is immoral. ${ }^{205}$

While there is certainly an overlap between this moral discourse and the public policy debates on related issues, the point is that the search for truth in the sense of social enlightenment is also advanced by the information produced by investigative deceptions. Again, to take agricultural investigations as an example since this industry is seeking special protection from investigative deceptions, in this context such lies serve to expose the hidden conduct of commercial agricultural operations. These revelations will impact the public's thinking about the morality of modern agricultural practices - the investigator cannot control the message that his videos convey, but one can be sure that they are shaping public opinion. ${ }^{206}$ Thus, under the truth serving theories of the First Amendment, investigative deceptions may be powerfully justified. ${ }^{207}$

Moreover, lies may even lead to a greater ability for society to deliberate about actual truth over the long run. As Wright observes:

Unquestionably, to lie to anyone, including an interrogating slave hunter or Nazi officer is, ordinarily, to

203 John Milton, Areopagitica 4 (1644); John Stuart Mill, On Liberty 82-83 (2d ed. 1859). See also Eugene Volokh, In Defense of the Marketplace of Ideas/Search for Truth as a Theory of Free Speech Protection, 97 VA. L. REV. 595, 596-98 (2011).

204 See Abrams v. United States, 250 U.S. 616, 630 (1919) (Holmes, J., dissenting).

205 See, e.g., Gary L. Francione, Animals as Persons: Essays on the Abolition of Animal Exploitation 3-21 (2008); Peter Singer, Animal Liberation: The Definitive Classic of the Animal Movement 94 (First Harper Perennial ed. 2009).

206 About Us, ASPCA (Feb. 17, 2012), http://www.aspca.org/about-us/press-releases/aspcaresearch-shows-americans-overwhelmingly-support-investigations-expose.

207 We distinguish this argument from claims that lies may be morally necessary not because they lead to truth, but because they advance morality at either the individual or societal level. See, e.g., Wright, supra note 7, at 1143-44; Varat, supra note 7, at 1122. 
fail to further the interrogator's true understanding of where his innocent quarry may be found. But on the other hand, such a lie (at least where successful), may over time promote the moral truths of the real consequences of slavery-ethnic and religious extermination, and genocide. Also to be factored in are such truths that the liar, the liar's family, and the sheltered slaves or Jews might later have discovered and perhaps shared. To obstruct the social systems of chattel slavery or Nazism, insofar as either amounts distinctively to a truth-suppressive institution, furthers the promotion of the truth. ${ }^{208}$

One might argue, in the context of either the democracy or the truthseeking theory, that investigative deceptions do not have intrinsic value, but rather have instrumental value. ${ }^{209}$ That is, investigative deceptions do not directly contribute to discourse, but are a tool to gather information that informs that discourse. The lie itself, so the argument would go, is not serving any truth or democracy enhancing purposes. It is certainly true that the lies like, "I hate PETA and I am not affiliated with any animal rights organization" or "I love eating bacon and I have no problem with killing animals" do not directly contribute to a debate of public importance in the same manner as, for example, "Meat is murder," 210 might. However, the courts have protected other types of speech and even conduct that is not itself expressive, but is nonetheless preparatory to speech. As the Court observed in Citizens United v. FEC, ${ }^{211}$ "laws enacted to control or suppress speech may operate at different points in the speech process." Indeed, the Court's campaign finance cases are all to some degree predicated on the notion that restrictions on fundraising and spending are limited by the First Amendment because they facilitate subsequent political speech. ${ }^{212}$ Thus, the distinction between intrinsic

208 Wright, supra note 7 , at 1157-58.

209 See Norton, supra note 7, at 164 ("Some lies have instrumental or even moral value.").

210 The Smiths, Meat is Murder, on Meat is Murder (Tokuma Japan Comm'n 1985).

211558 U.S. 310, 336 (2010).

212 See, e.g., Buckley v. Valeo, 424 U.S. 1, 19 (1976) ("A restriction on the amount of money a person or group can spend on political communication during a campaign necessarily reduces the quantity of expression by restricting the number of issues discussed, the depth of their exploration, and the size of the audience reached."). For the same reason, Ag Gag laws that directly restrict nonconsensual investigative video recordings also implicate First Amendment speech concerns. See Animal Legal Defense Fund v. Otter, No. 1:14-cv-00104-BLW, 2014 WL 4388158, at*10 (D. Idaho Sep. 4, 2014); see also ACLU v. Alvarez, 679 F.3d 583, 597 (7th Cir. 2012) (holding that the "act of making an audio or audiovisual recording is necessarily included within the First Amendment's guarantee of speech and press rights as a corollary of the right to disseminate the resulting recording."). We will discuss this in greater detail in a future article. 
and instrumental value of investigative deceptions is not material to our basic claim because lies either directly or instrumentally serve truth.

\section{Investigative Deceptions Promote Individual Autonomy}

The third widely cited First Amendment theory argues that the function of free speech is to promote individual autonomy or selfrealization. The autonomy theory focuses not on the value of speech to the broader society, but on its enhancement of the speaker's liberty. Thomas Scanlon defined autonomy as necessitating the protection of an individual's freedom to engage in self-determination in forming his or her own opinions and beliefs. 213

While autonomy arguments are probably the least weighty justification for First Amendment coverage of investigative deceptions, even here a case can be made. There is an extent to which laws barring investigative deceptions, such as Ag Gag laws, interfere with the autonomous choices of journalists, government agents, and activists to choose how to identify themselves in the context of an undercover investigation. Autonomy arguments have tended to focus on the freedom of the speaker to determine his or her own feelings, beliefs, and thoughts without government interference rather than on the liberty to frame (truthfully or falsely) one's identity. In that sense, lying does not obviously serve the goal of autonomy. Still, there are arguments that might focus us more on the way that lies may promote the autonomy of self-identity, whether it be for the purpose of individual self-esteem ("I am the best law professor in the world"), to gain respect from others ("I volunteer at the soup kitchen every week"), or to gain access to an area where one believes illegal conduct may be occurring ("I am not affiliated with any journalists and I am excited to do this work").

David Han has suggested that what he calls individual "selfdefinition" is an important aspect of autonomy that ought to be recognized under First Amendment doctrine. ${ }^{214}$ Thus, sometimes autobiographical lies may be a form of speech that may be protected as a means of promoting individual autonomy. As he observes, "Under any basic conception of autonomy, however, a fundamental component of

213 Scanlon, Theory, supra note 21, at 215. In later work, Scanlon modified his views about speech and autonomy. T.M. Scanlon, Jr., Freedom of Expression and Categories of Expression, 40 U. PitT. L. REV. 519 (1979). Other autonomy theorists took a slightly broader view that included the protection of the individual's ability to develop his or her powers and abilities and to control his or her own destiny through the autonomy of decision making. Martin H. Redish, The Value of Free Speech, 130 U. PA. L. REV. 591, 593 (1982).

214 David S. Han, Autobiographical Lies and the First Amendment's Protection of SelfDefining Speech, 87 N.Y.U. L. REV. 70, 92 (2012). 
being an autonomous individual is exercising control over who you areand who you are is, to a significant extent, a function of who you define yourself to be to others." ${ }_{215}$ Han's theory resonates, to some degree, with the Court's decision in Alvarez. ${ }^{216}$ Xavier Alvarez provided a biographical summary of his career after being elected to a local political position and he claimed to have served in the military and to have won the Medal of Honor. ${ }^{217}$ None of this was true, but the Court held that such lies - seemingly of minimal truth and governance value - were protected speech (though neither the majority nor the concurring opinion justified the invalidation of the Stolen Valor Act on autonomy grounds).

Consistent with this view, R. George Wright has suggested that lying might be better examined as part of a broader moral context, in which lies might advance personal autonomy and liberty in ways that supersede their moral costs. ${ }^{218}$ Analyzing lies in the historical context of an imagined lie to a fugitive slave hunter or Nazi officer seeking to find Jews during the Holocaust, Wright argues that lies might have moral value in advancing the autonomy of the liar, and those she seeks to protect from harm. "The lie may be instead motivated by a sense of the equal or irreplaceable value and infinite dignity of persons, or even by genuine concern for the questioner's moral or spiritual well-being." 219 At least in the context of Ag Gag laws, the same moral claim could be made for activists seeking to promote the dignity and autonomy of non-human animals, a central tenet of many animal rights groups. ${ }^{220}$

Balanced against these arguments is the countervailing loss of autonomy potentially experienced by the listener. This argument is often used to explain why lies ought not to be protected under the First Amendment. $^{221}$ Derived from the writings of Immanuel Kant and other moral philosophers, this claim suggests that lies are morally problematic because they deprive the listener of the very same autonomy that free speech is designed to promote. Kant was something of a truth "absolutist" in that he rejected an instrumental theory under which lies could ever be understood in context as socially valuable. As David Strauss has written:

215 Id. at 99.

216132 S. Ct. 2537, 2542 (2012).

217 Id.

218 Wright, supra note 7, at 1142 ("The obvious and quite substantial moral benefits of 'benevolent' lies should also be taken into account.").

219 Id. at 1146.

220 See, e.g., SINGER, supra note 212, at 239-40.

221 See Seana VAlentine Shiffrin, SpeEch Matters: On Lying, Morality, AND THE Law (2014). See also Wright, supra note 7, at 1143; Varat, supra note 7, at 1114. 
[The] Kantian account gives relatively clear content to the notion that lying is wrong because it violates human autonomy. Lying forces the victim to pursue the speaker's objectives instead of the victim's own objectives. If the capacity to decide upon a plan of life and to determine one's own objectives is integral to human nature, lies that are designed to manipulate people are a uniquely severe offense against human autonomy. 22

A couple of factors might mitigate the concern over listener autonomy in the context of investigative deceptions, including the Ag Gag laws. First, the agricultural employee who is lied to and allows access to a commercial facility or record is unlikely to be directly harmed by the lie in any material way. That is, to the extent that her autonomy is lost by being persuaded to permit an undercover investigator to enter an agricultural facility, it is not a personal loss, as it would be if her individual privacy were somehow compromised by the exchange. Lies that facilitate access to intimate, personal details may very well work too much harm to the listener's autonomy to be tolerated by the autonomy theory. One could argue that the business's autonomy is harmed by the lie insofar as it has lost complete control over its property. But it is not clear that a conception of autonomy grounded in a right to be free from whistleblowers and exposés ought to be taken seriously, and as long as there are still limits on collecting obviously protected information such as trade secrets or tax records, the harm of that autonomy loss is minimal or non-existent. ${ }^{223}$ Moreover, there is an "unclean hands" argument that where unsavory or illegal conduct is occurring and the business's employees are arguably complicit (or vicariously responsible), the loss of listener autonomy that occurs when an investigator lies to gain access to the property is at least less of a concern than it would be in other contexts. $^{224}$

222 See David A. Strauss, Persuasion, Autonomy, and Freedom of Expression, 91 Colum. L. Rev. 334, 335 (1991). See also C. Edwin Baker, First Amendment Limits on Copyright, 55 VAND. L. REV. 891, 910 (2002).

${ }^{223}$ See infra notes 270,323 and accompanying text.

224 Other leading scholars have rejected the view that lying harms the autonomy of listeners in all contexts. Wright, for example, suggests that a lie might paradoxically enhance rather than diminish the listener's autonomy. Wright, supra note 7, at 1145. He observes, "[c]ould not a lie to a murderous SS officer also promote the rationality, personhood, or dignity of that SS officer over the longer term?". Id. at 1143. Professor Volokh and Weinstein argued in their amicus brief to the Court in Alvarez that the Court ought to recognize a categorical exemption from constitutional protection for knowing falsehoods, while allowing narrow exceptions for "statements about the government, science, and history in order to avoid an undue chilling effect on true factual statements, statements of opinion, or other constitutionally valuable expression." 


\section{DOCTRINAL IMPLEMENTATION OF FiRST AMENDMENT Protection Of High VAlue Lies}

The previous section sought to demonstrate that, properly understood, investigative deceptions are a type of speech that is covered by the First Amendment. The remaining task is to describe how current doctrine would apply to laws that regulate or prohibit such lies, including Ag Gag statutes. In the following sections, we offer a thorough discussion of the appropriate level of scrutiny and identify the key limiting principles applicable to First Amendment protections for high value lies.

A. Considering and Applying the Proper Level of Scrutiny for Laws Criminalizing Investigative Deceptions

\section{Strict Scrutiny}

\section{a. Reading the Alvarez Plurality Tea Leaves}

Alvarez is the lone Supreme Court decision to directly address the First Amendment protection owed to lies. Because it is a fractured plurality opinion, the status of lies under the Constitution remains somewhat obscured. Six justices clearly held that some lies - even intentional, self-promoting lies - constitute protected speech. ${ }^{225}$ Likewise, six Justices recognize that only lies that cause material harm to the listener fall outside of the First Amendment as unprotected speech. ${ }^{226}$ The First Amendment extends beyond truth. The question of whether the Constitution requires strict or merely heightened scrutiny of government regulation of lies is much more opaque.

Because Alvarez includes no majority consensus on whether strict scrutiny applies, lower courts must toil through the impenetrable rule from Marks $v$. United States, ${ }^{227}$ which instructed that non-majority

Brief of Professors Eugene Volokh and James Weinstein as Amicus Curiae in Support of Petitioner at 2-11, United States v. Alvarez, 132 S. Ct. 2537 (2012) (No. 11-210), 2011 WL 3693418 , at $* 2-* 11$. Their rationale for this argument, however, is based primarily on a concern that allowing some protection for intentional lies might undermine the coherence of First Amendment doctrine and also lead to precedents that would dilute the strict scrutiny standard because courts would be inclined to uphold many government regulations of false statements of fact. Id. at 2.

225 United States v. Alvarez, 132 S. Ct. 2537, 2544-45 (2012).

226 Id. at 2545.

227430 U.S. 188, 193 (1977). 
opinions will generally create precedent. Under the Marks rule, "[w] hen a fragmented Court decides a case and no single rationale explaining the result enjoys the assent of five Justices, the holding of the Court may be viewed as that position taken by those members who concurred in the judgment on the narrowest grounds." 228 Of course when it comes to judicial reasoning the term "narrow" is rarely illuminating. For example, when the fundamental difference between the opinions concurring in the result is a core doctrinal disagreement, such as determining the applicable level of scrutiny, it may very well be that the Marks rule does not provide a single clear holding on that question. ${ }^{229}$ The difference between intermediate and strict scrutiny is one of kind not of breadth, and so it is simply not the case that one opinion is necessarily narrower than the other. ${ }^{230}$ Marks's narrowest grounds rule cannot and does not stand for the view that when the Court is fractured, the holding constitutes the opinion that articulates the most parsimonious view of constitutional rights.

Accordingly, while Alvarez reflects a clear majority rejecting the notion that lies are categorically unprotected by the First Amendment, it may not squarely answer the question of the degree of scrutiny that applies. ${ }^{231}$ Notably, a prior study of the Court's own use of the Marks rule suggests that when, as with Alvarez, there is no true common denominator of reasoning, no true narrowest grounds, the Court tends to defer to the lower courts in how to define the precedent from a prior Supreme Court plurality. ${ }^{232}$ Under this view, the precedential value of a plurality may be upward flowing from lower courts to the Supreme Court. ${ }^{233}$ Notably, a number of lower courts have held that strict scrutiny is the proper level of scrutiny for government actions prohibiting lies. ${ }^{234}$

228 Id.

229 Justin Marceau, Plurality Decisions: Upward-Flowing Precedent and Acoustic Separation, 45 ConN. L. REV. 933, 994 (2013) (explaining the Marks rule's proper application).

230 See, e.g., United States v. Gerke Excavating, Inc., 464 F.3d 723, 724 (7th Cir. 2006) (concluding that a plurality holding is "the narrowest ground to which a majority of the Justices would have assented if forced to choose"); Jackson v. Danberg, 594 F.3d 210, 220 (3d Cir. 2010) (recognizing that, in the absence of a true commonality of reasoning, there is no binding holding from the Supreme Court).

231 Id.

232 Marceau, supra note 229, at 994.

233 Id.

234 See, e.g., American Freedom Defense Initiative v. Southeastern Pennsylvania Transportation Authority, 2014 WL 6676517 (E.D. Pa. 2014) (recognizing that when the lies at issue are "political expression" the speech is "entitled to even greater First Amendment protection than the speech at issue in Alvarez"); O'Neill v. Crawford, 970 N.E.2d 973 (Ohio 2012) ("The Alvarez court recognized that not only must the restriction meet the "compelling interest test," but the restriction must be "actually necessary" to achieve its interest."); State ex rel. Loughry v. Tennant, 732 S.E.2d 507, 517 (2012) (quoting the plurality opinion from Alvarez for the view that 


\section{b. Restrictions on High Value Lies Warrant Strict Scrutiny}

The first two-thirds of this Article painstakingly develops the claim that not all lies are equal and that lies told in order to gain access to nonintimate information of considerable public concern ought to be recognized as distinct from all other lies. These investigative deceptions - misrepresentations that made the work of Upton Sinclair and his modern day heirs possible - should receive the utmost constitutional protection. Insofar as investigative deceptions facilitate the underlying goals of truth and self-governance undergirding the freedom of speech, such lies deserve correspondingly more protection than lies which are protected only because the failure to do so might chill otherwise protected speech. That is to say, the protection of intrinsically valuable lies surely must take priority over the protection of lies that are of no value. ${ }^{235}$ Accordingly, whether Alvarez prescribes strict scrutiny for all lies is of no moment when assessing whether high value lies are deserving of strict scrutiny.

In a decision addressing the constitutionality of a law that criminalized lies told about ballot initiatives, the Eighth Circuit held that because the law in question regulated politically salient speech on the basis of its content, it must be subject to strict scrutiny. ${ }^{236}$ Analogous reasoning compels the conclusion that strict scrutiny applies to investigative deceptions, like those criminalized by Ag Gag statutes. In Animal Legal Defense Fund v. Otter, the only reported decision in a challenge to an Ag Gag law, Judge Winmill denied a motion to dismiss by explaining, in relevant part, that laws criminalizing lies are contentbased and warrant strict scrutiny. ${ }^{237}$ This reasoning is unassailable.

"[W] hen the Government seeks to regulate protected speech, the restriction must be the least restrictive means among available, effective alternatives."); In re Judicial Campaign Complaint Against O'Toole, 141 Ohio St. 3d 355, 363 (2014) (assuming the application of strict scrutiny and observing "Alvarez does not consider whether the state can ever have a compelling interest in restricting false speech solely on the basis that it is false so that such prohibition could withstand strict scrutiny.”).

235 See Norton, supra note 7, at 163 (arguing that "[ $\mathrm{t}]$ he very ubiquity and diversity of lies thus supports a presumption that lies are fully protected by the First Amendment and that government therefore generally may not regulate them unless it satisfies strict scrutiny.").

236281 Care Comm. v. Arneson, 638 F.3d 621, 636 n.3 (8th Cir. 2011) (summarizing Supreme Court doctrine and recognizing that speech limits - even if indirect, such as limits on tort verdicts - that limit speech "about matters of public concern" are subject to the highest scrutiny) (quoting Garrison v. Louisiana, 379 U.S. 64, 74-75 (1964)); id. at 636 ("We do not, of course, hold today that a state may never regulate false speech in this context. Rather, we hold that it may only do so when it satisfies the First Amendment test required for content-based speech restrictions: that any regulation be narrowly tailored to meet a compelling government interest.").

${ }^{237}$ _ F.Supp.2d__ (D. Idaho Sep. 4, 2014), 2014 WL 4388158. 
Whatever level of constitutional protection is ultimately deemed appropriate for lies like those at issue in Alvarez - lies described as nothing more than a "pathetic attempt to gain respect" 238 - investigative deceptions that tend to facilitate truth and democratic debate ought to receive the highest level of protection.

\section{c. Strict Scrutiny Under Standard First Amendment Doctrine}

Even setting aside for a moment Alvarez and other lie-specific case law, it would be "puzzling" 239 to conclude that laws banning investigative deceptions would not receive strict scrutiny. Any law that is content discriminatory is subject to the most exacting standard of review, ${ }^{240}$ which requires that the government show that the law in question is the least restrictive means of serving a compelling governmental interest. ${ }^{241}$

Taking Ag Gag laws as an example, laws that criminalize investigative deceptions are indisputably content-based. Outlawing only parodies or jokes but not other types of expression would surely constitute a content-based limitation. ${ }^{242}$ Similarly, distinguishing between serious political speech and comical speech is not permitted. For the law to distinguish between truthful and untrue speech is to favor one form of content over another. If false statements are categorically exempt from the reach of the First Amendment, then perhaps the content discrimination in this context would not matter. But if we have successfully made the case that investigative deceptions are not exempt from constitutional scrutiny, then Ag Gag laws and their ilk are content based on this reasoning alone.

Moreover, Ag Gag laws are twice content-based. In addition to discriminating between truthful and false speech, these laws discriminate based on the content of speech because they specifically apply only to statements made in the context of gaining access to agricultural facilities. The reason the Court imposes heightened scrutiny on viewpoint and content discriminatory laws is that such laws raise serious concerns that the government is using its power to control and distort public

238 United States v. Alvarez, 132 S. Ct. 2537, 2542 (2012).

239 Erwin Chemerinsky, The First Amendment and the Right to Lie, ABA JournAL (Sept. 5, 2012 $1: 57$ PM),

http://www.abajournal.com/news/article/the_first_amendment_and the_right_to_lie/ (summarizing Alvarez concurrence suggesting intermediate scrutiny).

240 Turner Broad. Sys., Inc. v. FCC, 512 U.S. 622, 641-42 (1994).

241 Id. at 668. See also Hustler Magazine, Inc. v. Falwell, 485 U.S. 46, 52 (1988).

242 Turner Broad. Sys., Inc., 512 U.S. at 680. 
discourse. ${ }^{243}$ State action that protects agricultural facilities, but not other private business enterprises suggests that the government wishes to skew the debate about agricultural practices by steering public scrutiny away from this particular range of topics. A generally applicable law prohibiting all investigative deceptions would present a more challenging constitutional question. $^{244}$ But the $\mathrm{Ag}$ Gag laws criminalize only deceptions used to gain access and report on a single, massive and publicly important industry - indeed, in the rural states where these laws are most common agriculture may be the largest employer in the state. ${ }^{245}$ These same legislatures have not prohibited misrepresentations made to gain access to child care facilities, large banks, workplaces where labor law violations may be occurring, or companies that dispose of toxic waste material, just to name a few examples of other regulated businesses where undercover investigations have occurred.

Ag Gag laws single out the agricultural industry for protection against misrepresentations. Both the distinction between truth and falsity, and the effort to safeguard a single industry from the likes of investigative reporters, thereby driving certain information from the marketplace of public discourse, are independently sufficient to trigger strict scrutiny for Ag Gag laws.

That is not to say that investigative deceptions can never be criminalized. A journalist's efforts to expose national security matters or trade secrets may well constitute the sort of lie for which strict scrutiny is satisfied. ${ }^{246}$ A trickier question would be the use of deception to gain

${ }^{243}$ See, e.g., Simon \& Schuster, Inc. v. Members of N.Y. State Crime Victims Bd., 502 U.S. 105,116 (1991) (stating that content discrimination "raises the specter that the Government may effectively drive certain ideas or viewpoints from the marketplace.").

244 Generally applicable laws that have only an incidental effect on speech activities are subject to intermediate scrutiny. United States v. O'Brien, 391 U.S. 367, 376-77 (1968). Accordingly, traffic laws and the like are common examples of laws that, though they may impede a journalists efforts to gather a story, are not unconstitutional. By contrast, laws that criminalize the very means of gathering a story (misrepresentation) and do so in a manner that distinguishes among the type of targets for investigations can hardly be considered generally applicable laws.

245 See, e.g., Sean Ellis, Ag industry gives Idaho's economy a boost, Idaho State Journal (Jan. 9, 2011), http://www.idahostatejournal.com/news/local/ag-industry-gives-idaho-s-economy-aboost/article_38912470-1c85-11e0-b19a-001cc4c002e0.html; Di Lewis, Agriculture a Growing Contributor to Utah Economy, Utah Business (Feb. 11, 2013), http://www.utahbusiness.com/articles/view/agriculture_a_growing_contributor_to_utah_econo my; Charles O'Brien, Agriculture sector continues to grow in the Iowa economy,

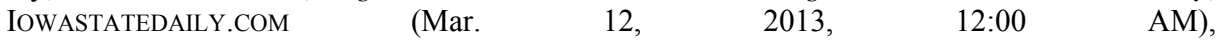
http://www.iowastatedaily.com/news/article_61e433f0-89af-11e2-9ada-0019bb2963f4.html.

246 Jane Bambauer, Is Data Speech?, 66 Stan. L. Rev. 57, 63-64 (2014) ("Privacy regulations are rarely incidental burdens to knowledge. ... Although the First Amendment creates a barrier to the enforcement of new and existing information laws, that barrier is not insurmountable. It simply requires, as it should, a lively inquiry into whether the harms caused by 
access to a facility or process by someone who does not know that trade secrets or other interests would be exposed or injured. Assuming trade secret laws and other privacy protections of this sort in the commercial context can withstand constitutional scrutiny, ${ }^{247}$ we think that the proper standard in assessing liability under the laws in such circumstances would be the public figure defamation standard. ${ }^{248}$ That is, if the person is malicious or reckless in revealing or benefitting from such protectable interests, then the lies told to gain access and the publication of such information can be criminalized. In this way, persons who lie with the intent of exposing a competitor's trade secrets or to cause physical injury to the facility can be criminalized without risking First Amendment injury. By contrast, most lies that result in the exposure of unsavory or illegal industry practices but do not compromise intellectual property or trade secrets, will be protected insofar as they are not made with the intent or reckless disregard of the risk of exposing trade secrets or similarly protectable interests. ${ }^{249}$ Upton Sinclair may have gained access to things that the slaughterhouse owner wished he had not seen, but he did not expose (nor did he intend to expose) any properly protected intellectual property.

\section{d. Strict Scrutiny under R.A.V. v. City of St. Paul}

An alternative doctrinal approach to examining the constitutionality of Ag Gag laws and other prohibitions on investigative deceptions would not even necessitate the analytically prior conclusion that investigative deceptions are speech covered by the First Amendment. In R.A.V. v. City of St. Paul, the Supreme Court held that laws regulating even unprotected speech must be subjected to strict scrutiny if they discriminate within that category of unprotected speech on the basis of content. ${ }^{250}$ After he allegedly burned a cross on the property of an African American family, the defendant was charged under a city ordinance that prohibited the display of a symbol which the defendant has reason to know "arouses

the collection of information are probable enough, and serious enough, to outweigh the right to learn things.").

247 Id.

248 New York Times v. Sullivan, 376 U.S. 254, 283 (1964).

249 To the extent that trade secret liability is defined too broadly or generically, these laws would themselves fail First Amendment scrutiny. And if deception is used to access a facility that contains trade secrets or the like, then certainly the investigator or reporter can take precautions to avoid revealing any of these protected secrets, just as any other employee would do. And a failure to take such precautions might justify liability under a statute punishing reckless disclosures of such information.

250505 U.S. 377, 383-84 (1992). 
anger, alarm or resentment in others on the basis of race, color, creed, religion or gender." 251 The state courts that had interpreted the ordinance had narrowed its construction to cover only conduct that was itself unprotected speech in the form of fighting words as defined by the Supreme Court in Chaplinsky v. New Hampshire. ${ }^{252}$

Notwithstanding the assumption that the ordinance only prohibited fighting words, the Court held that the ordinance was facially unconstitutional because "it prohibits otherwise permitted speech solely on the basis of the subjects the speech addresses." 253 As explained by Justice Scalia,

What [the cases announcing categories of unprotected speech] mean is that these areas of speech can, consistently with the First Amendment, be regulated because of their constitutionally proscribable content (obscenity, defamation, etc.) — not that they are categories of speech entirely invisible to the Constitution, so that they may be made the vehicles for content discrimination unrelated to their distinctively proscribable content. ${ }^{254}$

The Court elaborated further by drawing on the example of unprotected defamation. "[T] he government may proscribe libel," it said, "but it may not make the further content discrimination of proscribing only libel critical of the government." 255 By similar reasoning, even if the government could criminalize lying in general (or lying to gain access more specifically), criminalizing lies to gain access and expose only a single industry must be subject to strict scrutiny.

The regulation of lies by $\mathrm{Ag}$ Gag laws and similar statutes discriminates based on the type of facility sought to be accessed, and in some instances based on whether the individual intends to help or hurt the industry. ${ }^{256}$ Thus even if investigative deceptions might be generally proscribable, the law serves to effect a content-based discrimination "unrelated to their distinctively proscribable content." 257

To make this point more concrete, consider that the Alvarez plurality in dicta suggests that not all lies will constitute protected speech. In

251 Id. at 380 (emphasis added).

252 Id. at 381.

253 Id.

254 Id. at 383-84 (emphasis in original).

255 Id. at 384.

256 See, e.g., IDAHO CODE ANN. §18-7042(1)(d) (criminalizing lies used to gain employment but only if the individual intends to cause (economic) harm to the agricultural industry).

257 R.A.V., 505 U.S. at 383-84. 
particular both the plurality and the concurring opinion single out lies that harm another party, such as fraudulently obtaining employment for which one is not qualified, as an example of the type of lie that can be proscribed. ${ }^{258}$ As the plurality explains, "[w]here false claims are made to effect a fraud or secure moneys or other valuable considerations, say offers of employment," the First Amendment generally provides no protection." 259 On its face this passage seems to provide support for the view that laws criminalizing misrepresentations to gain employment are not protected by the First Amendment. ${ }^{260}$ But when the prohibition is industry specific (or motivated by speech suppressing impulse ${ }^{261}$ ), strict scrutiny is required.

The crux of R.A.V.'s analysis is that while the government may suppress certain categories of speech because of the harms that are uniquely associated with their expression, it may not discriminate within those categories because of its hostility toward its non-proscribable content or viewpoint. Just as it is permissible to criminalize all threats, but impermissible to criminalize only threats based on a particular viewpoint, so too it is flawed to assume that because (hypothetically) all lies to gain employment may be criminalized, lies to gain employment in one particular industry to expose misconduct can be criminalized.

Even if we were to concede that false statements of fact are a particularly worthless and harmful category of expression in the context of gaining employment or access, the state still would be constitutionally forbidden to criminalize lies in a selective manner reflecting its interest not in promoting truthfulness generally, but in inhibiting a lies in a particular realm of public discourse. ${ }^{262}$ As one leading First Amendment scholar has observed, "Singling out one or a small group of lies for

258 United States v. Alvarez, 132 S. Ct. 2537, 2547 (2012).

259 Id.

${ }^{260}$ Obviously, criminalizing lies to gain access unrelated to employment are unaffected by this dicta from Alvarez. See IDAHO CODE ANN. §18-7042(1)(a)-(c).

261 See Elena Kagan, Private Speech, Public Purpose: The Role of Governmental Motive in First Amendment Doctrine, 63 U. CHI. L. REV. 413, 452 (1996) (recognizing that the core inquiry in assessing whether a law is content-based is ferreting out improper legislative motive). See also Alan K. Chen, Statutory Speech Bubbles, First Amendment Overbreadth, and Improper Legislative Purpose, 38 HARV. C.R.-C.L. L. REV. 31, 85-87 (2003).

262 Although this type of discrimination differs slightly from content regulation about particular ideas, as in R.A.V., it is the conceptual parallel of that decision. Ag Gag laws are not designed to address the distortion of truth in the same sense as, say, perjury laws, but are rather motivated by the government's desire to prohibit revealing information about a particular topic the mistreatment of animals by commercial agriculture facilities. And this is not just any run of the mill topic, but one that has been the subject of intense public discourse in recent years. Such laws regulate lies not for the sake of regulating falsity, but to protect big agriculture from public scrutiny. 
government condemnation, while leaving others unregulated, signifies a "realistic possibility that official suppression of ideas is afoot."263

\section{Intermediate Scrutiny - High Value Lies as a Hybrid Speech Category}

Although we think it less plausible, we consider an additional possibility, which is that laws targeting investigative deceptions might be subject to intermediate, rather than strict, scrutiny under First Amendment doctrine. ${ }^{264}$ Justice Breyer's concurrence in Alvarez for himself and Justice Kagan suggests a preference for intermediate scrutiny as to the type of lie at issue in that case. ${ }^{265}$ As discussed above, investigative deceptions like those criminalized by Ag Gag statutes are materially distinguishable from the sort of lie at issue in Alvarez, which did not touch upon issues of public concern. Thus, even if Breyer's concurrence were viewed as the Alvarez holding on this question, it is unlikely that this opinion would be controlling in the context of high value, investigative deceptions. ${ }^{266}$ Nonetheless, even if intermediate scrutiny did apply, we think such laws are still vulnerable to invalidation.

When a law is deemed content-neutral, the Supreme Court employs a formulation of intermediate scrutiny drawn from its cases evaluating the constitutionality of content neutral regulations of the time, place, or manner of expression in public forums. ${ }^{267}$ In these cases, the Court has

263 Varat, supra note 7, at 1118 (citing R.A.V., 505 U.S. 377, 390 (1992)).

264 See Norton, supra note 7, at 183 (arguing that intermediate scrutiny is the appropriate standard for evaluating government regulation of lies).

265 United States v. Alvarez, 132 S. Ct. 2537, 2552 (2012) ("in this case, the Court's term 'intermediate scrutiny' describes what I think we should do").

266 Other potential arguments for considering intermediate scrutiny would be that lies are a sui generis type of speech, like commercial speech. See Central Hudson Gas \& Elec. Corp. v. Pub. Serv. Comm'n, 447 U.S. 557 (1980). Likewise, laws of general applicability that govern conduct are typically afforded intermediate scrutiny. United States v. O'Brien, 391 U.S. 367 (1968).

267 Another version of intermediate scrutiny had previously emerged in cases examining the constitutionality of government regulations of expressive conduct. In those cases, the Court held that the regulation can only be upheld if "it furthers an important or substantial governmental interest; if the governmental interest is unrelated to the suppression of free expression; and if the incidental restriction on alleged First Amendment freedoms is no greater than is essential to the furtherance of that interest." O'Brien, 391 U.S. at 377 . The Court has essentially acknowledged that time, place, or manner and speech/conduct tests are now the same standard. See Barnes v. Glen Theatre, Inc., 501 U.S. 560, 566 (1991); Ward v. Rock Against Racism, 491 U.S. 781, 798 (1989); Clark v. Community for Creative Non-Violence, 468 U.S. 288, 298 \& n.8 (1984); see also Ashutosh Bhagwat, Of Markets and Media: The First Amendment, the New Mass Media, and the Political Components of Culture, 74 N.C. L. REv. 141, 167-70 (1995) (describing the Court's merger of the time, place, or manner test with the speech/conduct test as the "Ward/O'Brien rule."). Moreover, it is "the Ward statement of the test has become the standard formulation." For 
said that such laws must be "narrowly tailored to serve a significant governmental interest," and they must "leave open ample alternative channels for communication of the information." 268 While this test is not as rigorous as strict scrutiny, it still imposes a substantial burden on the government in defending a law and is considered a form of heightened review. ${ }^{269}$ Indeed, the Court's most recent invocation of intermediate scrutiny in McCullen v. Coakley is revealing. ${ }^{270}$ Not only did the Court strike down a Massachusetts law that criminalized the mere conduct of standing (even without speaking or picketing) within 35 feet of the entrance of an abortion clinic, ${ }^{271}$ it emphasized that laws that impinge speech for content-neutral reasons will face exacting scrutiny. In particular, the Court explained that laws designed to avoid the problems associated with speech are strongly disfavored:

Even though the Act is content neutral, it still must be narrowly tailored to serve a significant governmental interest [and] [t]he tailoring requirement does not simply guard against an impermissible desire to censor. The government may attempt to suppress speech not only because it disagrees with the message being expressed, but also for mere convenience. Where certain speech is associated with particular problems, silencing the speech is sometimes the path of least resistance. But by demanding a close fit between ends and means, the tailoring requirement prevents the government from too readily "sacrific[ing] speech for efficiency." 272

Accordingly, the application of intermediate scrutiny to laws targeting investigative deceptions would require the state to articulate and defend its interests in criminalizing such lies by showing that the harm avoided is narrowly tailored to an important government interest." A general ban on all lies used for undercover access in an industry is surely too blunt a tool to survive such exacting scrutiny.

Assuming, for example, the government interest were in preventing people from fraudulently obtaining employment and thereby performing

\footnotetext{
a general discussion of the intermediate scrutiny test, see Geoffrey R. Stone, Content Regulation and the First Amendment, 25 WM. \& MARY L. REV. 189, 190 (1983) ("The Supreme Court tests the constitutionality of content-neutral restrictions with an essentially open-ended form of balancing.").

268 Ward, 491 U.S. at 791.

269 Bhagwat, supra note 267, at 169.

270134 S. Ct. 2518, 2530 (2014).

271 Id. at 2526.

272 Id. at 2534.
} 
jobs they are not qualified to perform, there is no material harm arising from such conduct if the undercover investigator is actually capable of performing the job tasks at hand. Thus, the law could be more narrowly drawn to address misrepresentations that actually interfere with the employer's ability to have its employees perform their assigned duties. In this way laws that prohibit lying about having a law license or similar professional training would likely survive First Amendment scrutiny. A general ban on lies to gain employment (much less general bans on all misrepresentations to gain access, which encompass employment lies) would not survive strict scrutiny.

Similarly, if the state's interest is targeted at the illegal acquisition of confidential information, such as trade secrets, a law could be narrowly drawn to regulate that conduct in particular. Indeed, many trade secret and intellectual property laws are likely constitutional for exactly this reason. By contrast, laws that are written as broadly as the Ag Gag statutes manifest an intention not to address legitimate interests in property or fraud prevention, but to criminalize the conduct of undercover investigators in order to suppress their speech.

Finally, intermediate scrutiny also typically requires that the law in question leave "open ample alternative channels" for the speech impinged by the law in question. ${ }^{273}$ For any industry, but particularly in the secretive agricultural industry, it is unlikely that any viable alternatives to undercover whistleblowing exist. The lies are speech (or conduct) that facilitate the production of undercover videos showing the real time production of food. Merely pointing to the ability to protest on the street or leaflet or hold rallies is no answer to the law's ability to utterly foreclose access to investigative reporting in the agricultural industry. There really is no ample alternative forum through which activists and journalists might carry out this type of expression, and thus even under intermediate scrutiny, these Ag Gag laws would be found to be an unconstitutional infringement of expression. ${ }^{274}$

${ }^{273}$ Id. at 2522.

$274 \mathrm{Ag}$ Gag laws and similar statutes criminalizing investigative deceptions are also vulnerable to claims that they are unconstitutionally overbroad. The First Amendment overbreadth doctrine requires that laws be invalidated when they restrict significantly more speech than the First Amendment allows. Criminal statutes must be examined particularly carefully. Such laws are particularly dangerous from a First Amendment perspective because of their potential to chill important expression. Overbreadth law protects individuals who "may well refrain from exercising their rights for fear of criminal sanctions provided by a statute susceptible of application to protected expression.” Gooding v. Wilson, 405 U.S. 518, 521 (1972). Ag Gag laws typically criminalize a wide range of conduct, some of which is not protected by the First Amendment (such as using force to enter, obtain records from, or obtain employment with an agricultural production facility), but a substantial amount of which is protected expression under the First Amendment, such as using misrepresentations in further of an animal welfare 


\section{B. Limiting Principles - Cognizable Harm as a Precondition to Criminalizing Lies}

The previous discussion attempts to situate investigative deceptions within the Court's tiers of scrutiny for the First Amendment and concludes that strict scrutiny most likely applies to laws criminalizing such lies. But even if investigative deceptions are recognized as high value speech subject to strict scrutiny, it is important to note that the law would still leave the government ample room to regulate material misrepresentations that endanger identifiable and tangible privacy and property interests. A critical piece of the doctrinal framework for understanding high value lies is developing a coherent set of limiting principles, which we attempt to do in this final section.

The most significant limiting principle is easily stated: Lies that cause material third party harm fall outside the ambit of the First Amendment's protection. ${ }^{275}$ Both the plurality and Justice Breyer's concurrence in Alvarez recognized this as limit on the protections afforded to lies by noting variously that the lie must not produce "legally cognizable harm" 276 or be used to gain "material advantage" 277 ; and that the lie must not have caused "actual injury" 278 or "specific harm." the government may not criminalize lying "in contexts where harm is unlikely." 280 As we discuss in this section, it is, therefore, necessary to define with some specificity what constitutes a legally cognizable harm in the context of investigative deceptions. Regulations of lies that cannot fairly be regarded as the legal cause of an injury are protected speech and subject to either strict or intermediate scrutiny, depending on the analysis above.

investigation. Because the laws often prohibit any type of misrepresentation used to gain access to an agricultural operation, they reach a wide range of expression, including, but not limited to, falsely asking to use a restroom to gain access to a property to failing to disclose one's political affiliations. As such, they sweep well beyond the scope of conduct that may be constitutionally regulated. Moreover, a law is more likely to be deemed overbroad if it is impinging speech of particular political salience. Richard Fallon, Making Sense of Overbreadth, 100 YALE L.J. 853, 894 (1991).

${ }^{275}$ But see Norton, supra note 7, at 187-99 (dividing harms into "second-party" (i.e., listener) and "third-party" (i.e., broader social) harms.)

276 United States v. Alvarez, 132 S. Ct. 2537, 2545 (2012).

277 Id. at 2548.

278 Id. at 2554 (Breyer, J., concurring).

279 Id. at 2556. Id at 2255 (noting that "proof of injury" is a general requirement for outlawing lies).

280 Id. at 2555. 
As Professor Varat has observed, there are two main categories of potential interests that might limit First Amendment protection for lies designed to secure truthful information. The first possible interest would be in protecting the listener from "psychological or pecuniary harm" that the investigative deception caused "directly and independently." 281 Second, there is a potential indirect harm caused by "the subsequent publication of the accurate information obtained as the result of the lie." 282 We address each of these categories in the following sections.

\section{Possible Direct Harms}

There are, of course, easy examples at both extremes of the spectrum of direct harms caused by lies. Defamation causes financial and reputational harm and falls beyond the scope of First Amendment protection. $^{283}$ The same is true of common law fraud, which has as an element actual injury. ${ }^{284}$ Likewise, crimes like perjury or lying to government officials impose materiality requirements, which typically require a showing of some likely injury or harm flowing from the lie, ${ }^{285}$ and in any event lies that may cause our democratic system of governance to falter are always safely categorized as harm causing. On the other end of the spectrum fall white lies and puffery. Intentionally lying and telling a co-worker that he does good work, or that he always dress professionally, for example, is clearly protected speech. ${ }^{286}$

It is not terribly difficult to fit laws barring investigative deceptions such as Ag Gag laws into this framework. To the extent that Ag Gag laws impose criminal penalties on misrepresentations to gain access to agricultural operations, they do so without reference to any tangible harm caused by the misrepresentations themselves. The laws criminalize the

281 Varat, supra note 7, at 1122-23.

282 Id. at 1123.

283 Dun \& Bradstreet, Inc. v. Greenmoss Builders, Inc., 472 U.S. 749, 760-61 (1985).

284 Alvarez, 132 S. Ct. at 2545.

285 Materiality in this context is often defined as lies which could have affected the outcome of a governmental proceeding. COLO. REv. STAT. ANN. § 18-8-501(1) (2014 West) ("affected the course or outcome of an official proceeding, or the action or decision of a public servant, or the performance of a governmental function"). More importantly, it is recognized that perjury undermines the credibility and legitimacy of our justice system, thus causing a grave social harm. See, e.g., Nicole Oelrich Tupman \& Jason Tupman, No Lie About It, the Perjury Sentencing Guidelines Must Change, 59 S.D. L. REv. 50, 64 (2014); John L. Watts, To Tell the Truth: A Qui Tam Action for Perjury in A Civil Proceeding Is Necessary to Protect the Integrity of the Civil Judicial System, 79 TEMP. L. REV. 773, 785 (2006) ("the judicial branch has a genuine interest in addressing the harm that perjured testimony causes to the civil judicial system.").

286 See, e.g., United States v. Alvarez, 638 F.3d 666, 673 (Kozinski, J., concurring in denial of rehearing en banc) (cataloguing a long list of such lies and identifying the lie as an essential feature of modern communication). 
access itself and any other harm that occurs during the course of the entry - whether it be the theft of property, destruction of property, or loss of trade secrets - is independent from and separately punishable under distinct criminal provisions.

\section{a. Trespass}

One likely basis for a legitimate assertion of harm to a protected interest would be the property right to possession. One who enters through deception, so the argument goes, would be harming the exclusive possessory interests of agricultural operations owner in ways analogous to a trespass. ${ }^{287}$ Notably, however, it is axiomatic under common law that civil trespass complainants need not show actual damages as a precondition of liability. ${ }^{288}$ Liability for trespass will presumptively only result in the imposition of nominal damages, and any recovery of more than that requires a showing of actual damage. ${ }^{289}$ That is to say, even if one strains to categorize entry through deception as trespass, because trespass is understood generally as imposing liability without harm, there is no basis for understanding all such deceptions as beyond the realm of First Amendment protection. Quite the contrary.

There is generally no harm cognizable at law caused by entry gained through investigative deceptions. As Judge Posner has vividly explained, entry into a business through deception where one wants or invites entry (but does not know the investigators true purpose) is not a true trespass because in such cases there is no invasion of the "the specific interests that the tort of trespass seeks to protect." 290 Needless to say, if an undercover investigator actually caused physical damage to property, personal injury, or some other tangible harm arising from an

28717 Wash. Prac., Real Estate $\S 10.2$ (2d ed.) (2014) (consent can be a defense to trespass, "provided it was not obtained by fraud, misrepresentation, or duress. . .."); Food Lion, Inc. v. Capital Cities/ABC, Inc., 951 F. Supp. 1217, 1222-23 (M.D. N.C. 1996). But see Laurent Sacharoff, Constitutional Trespass, 81 Tenn. L. Rev. 877, 882 (2014) (suggesting that trespass advances privacy interests).

288 Joseph William Singer, Property 28 (3d ed. 2010).

289 See, e.g., IDAHO CODE, §18-7008(A)(9) (establishing a misdemeanor for "Entering without permission of the owner or the owner's agent, upon the real property of another person which" is posted with proper signage indicating that the property is private and may not be trespassed upon). Interestingly, all other provisions of the Idaho criminal trespass statute entail actual tangible harm to the property. Id. at §18-7008(A)(1)-(8), (10).In contrast it is common for statutory trespass actions to require actual damages. While some state criminal trespass laws may be enforced even without a showing of actual harm, it is widely recognized that the sort of privacy and property rights protected by trespass laws are simply not served by punishing someone who gains access through deception.

${ }^{290} I d$. 
investigation, she could be held criminally or civilly liable. But the act of accessing a place through deception does not in and of itself cause a legally cognizable harm. ${ }^{291}$ The absence of any harm and the "inevitable effect" of the laws on investigative journalism and other speech activities doubtlessly implicates First Amendment protection. ${ }^{292}$

\section{b. Interference with Business Operations and Hiring Practices}

Another interest that the state may legitimately protect is the agriculture enterprise's ability to carry out its business lawfully. Thus, any misrepresentation that leads to direct interference with business operations (as distinguished from the self-inflicted economic harm resulting from the exposure of unlawful treatment of animals) could be constitutionally punished. Similarly, the state has a legitimate interest in helping businesses protect trade secrets and other secret proprietary information that allows them to fairly compete in the economic marketplace. ${ }^{293}$ Again, misrepresentations that are used to secure such information are within the state's authority to regulate because the harm that is avoided is concrete. But they are also clearly covered by more specific available legal remedies, and therefore these interests are satisfied by less restrictive alternatives than laws that ban investigative deceptions.

There is another way of viewing the state's interest in protecting business operations, and that is through the idea that investigative deceptions might interfere with a business's hiring practices, as opposed to its general operations. As the Alvarez plurality emphasizes, the First Amendment does not protect fraudulent speech, which may include lies made in order to "secure moneys or other valuable considerations, say offers of employment." "294 As to lies by undercover investigators who seek employment, then, that might seem to be the end of the matter as a cursory reading of Alvarez would suggest that employment securing lies are beyond the First Amendment. But the matter is not so simple. Not all lies to gain employment are on equal footing. The passages in Alvarez

${ }^{291}$ Lies to reveal intimate, private details may present different questions. As Judge Posner has elaborated, "If a homeowner opens his door to a purported meter reader who is in fact nothing of the sort - just a busybody curious about the interior of the home - the homeowner's consent to his entry is not a defense to a suit for trespass." Desnick v. Am. Broad. Companies, Inc., 44 F.3d 1345, 1352 (7th Cir. 1995)

${ }^{292}$ United States v. O'Brien, 391 U.S. 367, 385 (1968).

293 Id. at 1352 ("if a competitor gained entry to a business firm's premises posing as a customer but in fact hoping to steal the firm's trade secrets," that would be trespass) (citing Rockwell Graphic Sys., Inc. v. DEV Indus., Inc., 925 F.2d 174, 178 (7th Cir.1991)).

${ }^{294}$ United States v. Alvarez, 132 S. Ct. 2537, 2547 (2012). 
regarding employment are dicta because the Court was not considering a lie used to get a job, much less the diversity of employment related lies, some of which are surely protected and some of which are just as clearly not.

To put the issue of employment-based investigative deceptions in context, consider the lies told by Xavier Alvarez and their potential impact. Alvarez's lies about his military experience and honors were not the sort of generic puffery that would have struck many judges as protected speech; instead, they were the sort of lies that are designed to gain credibility or at least reputational benefits on the lying speaker. ${ }^{295}$ Such lies, though perhaps not persuasive to many, were made, according to the Supreme Court, in order to "gain respect" from the public and his fellow board members. ${ }^{296}$ In other words, the lie was made intentionally, and with the purpose of securing undeserved respect in the community, something that is not trivial to politicians, even local politicians. Yet because the lie did not cause any legally cognizable injury, six Justices agreed it was protected speech. ${ }^{297}$ If a politician's lies about accomplishments, even military honors, are protected speech, then the range of lies that cause cognizable harm is relatively small and a vast range of mistruths is entitled to First Amendment protection.

One particularly important category of lie that is unlikely to cause an injury sufficient to place it outside of the First Amendment's protections is lies to gain access to an agricultural facility by investigators pretending to seek employment or other false pretense for entering the premises. On the one hand, telling an employer that he has beautiful kids, or that you have always dreamed of working in a slaughterhouse, or even that you are a born again Christian, might very well impact one's decision to hire you. In that sense the lie is relevant, and maybe even material, to the employment decision. But such lies are not the sort of harm-causing, material lies that fall outside the First Amendment. The harm that befalls an employer following such an employment decision, if any, is the harm of exposing non-defamatory information discovered during the employment to the public. ${ }^{298}$ Similarly, loyalty to a cause might make one a more desirable employee, but omissions or misrepresentations about political or ideological disagreement with the industry or employer

${ }^{295} \mathrm{Id}$. at 2542.

${ }^{296}$ Id.

${ }^{297}$ Id.

298 Desnick, 44 F.3d at 1355 (recognizing that both the "broadcast" and the "production of the broadcast" are protected by the First Amendment and noting that the target of an undercover exposé has no legal harm when the business secrets are revealed even if e target has no legal remedy even if the "investigatory tactics used by the network are surreptitious, confrontational, unscrupulous, and ungentlemanly."). 
fall into the class of lies to which the First Amendment applies, because there is no harm as a matter of law. ${ }^{299}$ Simply failing to disclose an investigative purpose does not, without more, cause legally cognizable injury any more than failing to disclose a desire to unionize a workplace. $^{300}$

On the other hand, a wide range of employment related lies might easily be characterized as falling outside the reach of the First Amendment. Lying about one's qualifications for a job - claiming to have a law degree or training in the operation of heavy equipment, or other certificates or special skills - are quintessential examples of lies that typically do not enjoy First Amendment sanction. These lies relate to the essential function or task of the job and can cause cognizable injury to employers by exposing them to liability risks as well as an unsafe or unqualified work force. Work that is done less safely or less productively is a cognizable injury and lies made to shield inexperience or lack of credentials may cause such injury. Such fraudulent representations might lead to actual and direct harm to a business's operations and perhaps to harm to third parties, as in the case of an employee who creates safety risks because she is not trained in the way she represented. ${ }^{301}$ But when the lie has no bearing on the requisite qualifications of the individual and no relationship to the ability of the individual to safely and effectively perform the work in question, the First Amendment clearly implicated.

Strikingly, even the wages paid to undercover investigators who take employment based on lies will not generally result in harm to the employer that is proximately caused by the lies so long as the employees perform all of their duties competently. That is to say, a lie that enables a journalist to obtain paid employment and thus causes the employer to experience the most concrete and measurable harm - a financial expense - is not a legally cognizable harm. As the leading circuit court decision on this point explains:

${ }^{299}$ Of course, answering this threshold question - the very question at issue in Alvarez - does the First Amendment apply at all, is not the end of the inquiry. If a factual showing can be made that lies about loyalty, among other things, materially harm the employer, than the lie might still be criminalized because appropriately tailored legislation could satisfy strict scrutiny. But these are generally factual questions - does the law satisfy the applicable scrutiny. Our goal is to make clear that as a legal matter such scrutiny should be applied, and such a factual showing must be made.

${ }^{300}$ For example, "salting" is a common union practice whereby union organizers seeking to organize a particular employer's workforce may apply for a job without disclosing their status as a salt or union organizer. See e.g., Harman Bros. Heating \& Air Conditioning, Inc. v. NLRB, 280 F.3D 1110, 1111 (7th Cir. 2002) ("The only purpose of criminalizing such a lie could be to discourage salting, an activity protected by the [National Labor Relations] Act."

301 Thus, where tangible harms result, the constitutional implications are different. See Cohen v. Cowles Media Co., 501 U.S. 663, 665 (1991) (rejecting newspaper's First Amendment defense to suit by confidential source who claimed the newspaper breached its promise to protect his identity from public disclosure resulting in the loss of his job). 
The question is what was the proximate cause of the issuance of paychecks to Dale and Barnett. Was it the resume misrepresentations or was it something else? It was something else. Dale and Barnett were paid because they showed up for work and performed their assigned tasks as Food Lion employees. Their performance was at a level suitable to their status as new, entry-level employees. Indeed, shortly before Dale quit, her supervisor said she would "make a good meat wrapper." And, when Barnett quit, her supervisor recommended that she be rehired if she sought reemployment with Food Lion in the future. In sum, Dale and Barnett were not paid their wages because of misrepresentations on their job applications. $^{302}$

If a lie to gain employment does not cause a legal "injury" to the employer who pays the wages, then a wide range of injuries suffered by the employer (or accessed party) are also not caused by the lie. ${ }^{303}$ Certainly, the run of the mine lie about one's interest in the field, an underselling of one's credentials, a lie about political or ideological beliefs, or a lie about investigative motives does not cause such harm, and as such these lies fall within the First Amendment protections recognized in Alvarez. ${ }^{304}$

\footnotetext{
302 Food Lion, Inc. v. Capital Cities/ABC, Inc., 194 F.3d 505, 514 (4th Cir. 1999); id. (holding that lost sales and profits were not caused by the undercover investigation but by the information disclosed by the publication of the investigation's findings).

${ }^{303}$ Food Lion stands for the proposition that the harms occasioned by investigative reporting are "caused not by [the Reporter's] conduct but by Food Lion's own labor and food handling practices." Symposium, Panel I: Accountability of the Media in Investigations, 7 FordHAM INTELl. Prop. MEDIA \& ENT. L.J. 401, 424 (1997).

304 Of course, a wide range of injuries suffered by an employer can fairly be said to have been caused by a lie. Criminalizing deceptive entry for the purpose of stealing intellectual property, clients or trade secrets is likely permissible. Likewise, acts of terrorism or sabotage or the like committed by persons gaining access under false pretenses will always be the cause of injury to the victimized employer or citizen, and the lies that make such acts possible could be criminalized. Perhaps even lies about one's desire to remain employed for an extended period of time with the same employer could give rise to actual cognizable harm in certain instances. But even in the face of explicit lies about one's desire to remain employed, it may be difficult to show that such a lie caused the damage in question. See Food Lion, 194 F.3d at 513 ("Because Dale and Barnett did not make any express representations about how long they would work, Food Lion is left to contend that misrepresentations in the employment applications led it to believe the two would work for some extended period. There is a fundamental problem with that contention, however. North and South Carolina are at-will employment states, and under the at-will doctrine it is unreasonable for either the employer or the employee to rely on any assumptions about the duration of employment. At-will employment means that (absent an express agreement)
} 
Finally, while employers might argue that investigations resulting from deceptive employment applications breach a common law duty of loyalty arising from the employment relationship, those duties have typically been limited to direct interference with the employer's business operations, as where an employee directly competes with her employer, misappropriates property, profits, or business opportunities, or breaches confidences, such as revealing trade secrets. ${ }^{305}$

In short, lies about sexual orientation, love of sports, or marital status, no less than lies about fidelity to the employer's cause, may impact the employment decision. But these lies do not obviously cause any concrete injury to the employer. As such, the lie should be viewed as speech (or conduct facilitating speech) and the regulation should be subjected to heightened scrutiny. ${ }^{306}$

\section{c. Privacy and Autonomy}

Finally, a law may legitimately protect reasonable expectations of individual privacy on commercial premises. Speech is always entitled to more protection if it is of public concern, and thus investigative deceptions may serve to facilitate politically important speech on issues relating to how certain industries are operating. But the importance of speech about an industry does not make everything that happens at the facility politically significant. Thus, a law that forbade someone from gaining access to private information, such as individual income tax or health insurance records, or to areas of a commercial enterprise in which expectations of privacy are commonplace, such as workplace restrooms or employee locker/changing rooms, would advance valid personal privacy concerns. The First Amendment provides less protection when the privacy implicated is of a personal nature, and this is no less true in the context of lies that are preparatory to an investigative entry. Many lies to gain access will cause no cognizable harm and are thus protected by the First Amendment, but lies to gain access in ways that are harmful to personal dignity or to concrete business interests do not deserve constitutional sanction.

employers are free to discharge employees at any time for any reason, and employees are free to quit.").

305 Food Lion, 194 F.3d, at 515-16.

${ }^{306}$ If a particular employer or industry can meet the burden of proof required for heightened scrutiny - some showing, for example, that a particular lie or class of lies will cause financial harm based on empirical data, then a law narrowly tailored to prevent that particular type of lie will likely survive constitutional scrutiny. 
Furthermore, independent of actual privacy concerns, is the previously discussed matter of the deprivation of listener autonomy. We have already addressed that potential interest in our discussion about how high value lies advance the speaker's autonomy. ${ }^{307}$ In addition, as Helen Norton has argued, the privileging of listeners' over speakers' autonomy "would empower the government to punish a wide swath of lies and thus frustrate an antipaternalistic understanding of the First Amendment." 308

\section{. 2. Possible Indirect Harms Caused By Public Disclosure}

While it may be difficult to identify any direct harms from investigative deceptions, it is easy to recognize indirect harms to an employer exposed to an investigative reporting effort. One such harm that cannot be denied in the realm of investigative deceptions is the reputational injury that flows from the publication of an exposé. Businesses universally seek to exclude undercover investigations because of the risk of backlash in the form of boycotts or bad publicity. A critical source of the injury in cases of journalistic investigations is the publication and distribution of information or images obtained during the access that was gained by deception. For instance, the harm that befalls a childcare facility exposed by an undercover employee investigation by Dateline NBC is the damage to its reputation when the public sees, for example, the abusive treatment of children. The harm to a grocery store that is exposed for repackaging adulterated meat products by investigators is the exposure of its unsanitary practices. Likewise, the harm to an agricultural facility from an undercover employment investigation is the public reaction to the food safety, animal welfare, and labor issues that are documented or reported by the investigator.

These are serious harms. And at an intuitive level they are "caused" by the deceptive entry into the business. However these are not harms that can be criminalized. The harm that flows from public disclosure and debate about non-defamatory material is a harm qualitatively different than any other harm to one's property or privacy interests. ${ }^{309}$ When the harm sought to be avoided is the publication of truthful information of public concern, the First Amendment is uniquely implicated for at least two reasons. ${ }^{310}$

\footnotetext{
307 See supra notes 221-224 and accompanying text.

308 See Norton, supra note 7, at 190.

309 Cf. Food Lion, 194 F.3d at 522 ("The publication damages Food Lion sought (or alleged) were for items relating to its reputation, such as loss of good will and lost sales").

310 See Susan M. Gilles, Food Lion as Reform or Revolution: "Publication Damages" and First Amendment Scrutiny, 23 U. ARK. LiTTLE Rock L. REV. 37, 60 (2000) ("It suggests a unifying
} 
First, harms borne of publication on issues of public concern, and the concomitant public discourse that results, are harms that cannot fairly be traced to the lie that created the opportunity for the exposure. ${ }^{311}$ Of course, it is true that without publication there would be no reputational harm, but the First Amendment cannot tolerate a limitation on lies simply because they may lead to the publication of information that is otherwise unavailable, at least not when the information is non-intimate, nondefamatory, and of great political importance. ${ }^{312}$ Just as the wages paid to the employees conducting undercover investigations are not caused by the lie but by the work that was completed, the harm of publication is not caused by the lie, but by the bad acts that the investigator recorded or documented. The lie itself facilitates access, and if one does poor work or appears disloyal, or overly snoopy, he can be fired at will; the lie is instrumental to publication but is not the true cause of the harms of publication. ${ }^{313}$ As one commentator has summarized the law:

constitutional principle for all actions against the media precisely because it treats the cause of action filed as irrelevant. First Amendment scrutiny is triggered if a plaintiff seeks damages based on publication.").

311 But see Dietemann v. Time, Inc., 449 F.2d 245, 250 (9th Cir. 1971) ("No interest protected by the First Amendment is adversely affected by permitting damages for intrusion to be enhanced by the fact of later publication of the information that the publisher improperly acquired."). A number of cases dating back to an era of very different and more robust expectations of privacy reach similar conclusions, extending the media's liability for newsgathering torts to damages arising from the ensuing publications. Sims, supra note 170, at $542 \mathrm{n} .187$ (1998) (compiling such cases). These cases have been rightly and roundly criticized by the few commentators who have paid attention to them. See, e.g., Jacqueline A. Egr, Closing the Back Door on Damages: Extending the Actual Malice Standard to Publication-Related Damages Resulting from Newsgathering Torts, 49 U. KAN. L. REV. 693, 712-13 (2001) ("The Dietemann court erred in simply relying on the common law without incorporating First Amendment principles into its decision. Although Dietemann allegedly sought damages for invasion of privacy, the real harm, arguably, was his loss of reputation or esteem in the community resulting from the publication of the article and photographs disclosing his medical 'quackery.' Based on this theory, the court allowed Dietemann to recover damages coextensive with those awarded for a defamation claim without meeting the actual malice standard.").

312 A case that is frequently cited in defense of Ag Gag statutes is Houchins v. KQED, Inc, which, through a fractured plurality, denied the press unlimited access to a prison facility. 438 U.S. 1, 15 (1978). Notably, however, the controlling concurrence in Houchins, Justice Stewart's concurrence, explains that the First Amendment's freedom of press is not a mere redundancy. Id. at 16. If ever the Court should recognize a distinct freedom of press right, it should be in the context of lies to gain access, to non-intimate details of great political significance.

313 The defamation related protections are designed to protect against allegations of injury arising from publication. Some have argued that in newsgathering cases, the injury to the plaintiff occurs during the investigation and prior to publication, thus arguing that speech rights are less implicated by limits on investigations through generally applicable laws. Sims, supra note 170, at 526. In the Ag Gag context, however, exactly the opposite is true. The lie is the act of speech that facilitates an investigation and eventual publication. Arguably any harm from publication is too attenuated from the lie itself to justify depriving the lie of First Amendment protection. 
Courts have advanced several reasons why publication damages are not the proximate cause of newsgathering torts. Some follow the Food Lion district court's conclusion that the acts of the plaintiff depicted in the publication are the real proximate cause of publication damages, rather than newsgathering torts that merely facilitated access to learning about those acts. Others give no reason at all. ${ }^{314}$

As explained immediately above, lies that do not implicate the essential qualifications or functions of the job, but rather omit or affirmatively conceal journalistic or investigative motives, do not proximately cause harm by exposing unsavory or criminal acts observed as an undercover employee. Such investigative deceptions are surely the cause in fact, in the sense that it is logical to believe that an employer would not offer a job to someone looking to document and expose unseemly or illegal industry practices. But the lie to gain employment in these contexts does not produce any legally cognizable harm because the lie is not the proximate cause of any reputational injury. An action is said to be the legal or proximate cause of harm only if it causes the harm through a "natural and continuous sequence, unbroken by any efficient intervening cause." 315 Stated differently, the law of causation and the First Amendment cannot countenance a system in which the exposure of one's wrongdoing is treated as an actionable cause of the injury that flows from the exposure. ${ }^{316}$ To imagine such a regime of free speech law is to turn the First Amendment on its head insofar as the more newsworthy and politically salient the investigative publication - the more effective the investigation and the more damaging its revelations - the lower the First Amendment protection and the more likely there would be

314 Nathan Siegel, Publication Damages in Newsgathering Cases, 19 ComM. LAw. 11, 15 (2001) ("One reason the means by which raw information is obtained is not the proximate cause of publication damages is because that raw information harms no one. Rather, damage is caused by the way that information is subsequently presented in the publication, including the meaning that the publication ascribes to it editorially. Thus, the content and viewpoint of the ultimate publication, and the decisions made to express that content, are the proximate causes of publication damages.); id. ("inherent in the concept of proximate cause is that something more than literal causation is required. In addition, policy judgments must be made about the appropriate allocation of responsibility for harms involving a particular course of conduct.").

315 James Angell McLaughlin, Proximate Cause, 39 HARv. L. REv. 149, 185 n.99 (1925).

316 The illegal or unsavory acts documented by an undercover investigator are the intervening cause that breaks the chain. If an investigator gains employment at a childcare facility and documents unsafe or criminal interactions with the children, neither the recording nor the recorder are the cause of the harm that will flow to the business; rather the practices which are exposed are the cause of harm. 
damages. ${ }^{317}$ By such logic an undercover investigation showing that a business is an ongoing criminal enterprise would be less protected than an investigation that did not reveal any wrongdoing.

Defenders of Ag Gag laws and similar prohibitions might argue that the actual cause of cognizable harm to a business is the editing of the raw footage showing wrongdoing. Indeed the history of Ag Gag laws is replete with references to the fact that the agricultural industry and their supporters view with great suspicion the editing that investigators in these industries conduct before publishing the videos. ${ }^{318}$ Legislators and industry representatives have repeatedly referred to the investigations as orchestrated or staged, and on this basis justified the Ag Gag laws. Of course, if the harm is staged or unfairly edited videos, then "the real conduct being challenged .... is editorial conduct, not newsgathering [and] ... publication damages should only be permitted through the tort that challenges those decisions directly, defamation, rather than through fraud or trespass claims that have nothing to do with editorial content." 319 Bypassing the limits on defamation liability by using other tort claims is already prohibited under the common law, and when the circumvention of defamation limits takes the form of a criminal statute, the First Amendment concerns are even greater.

To state the matter as plainly as possible, even if one could say that the lie causes harm by making possible the recordings and eventual media attention, the resulting reputational harm to the investigated business is not a cognizable injury. The Supreme Court has been steadfast in holding that the First Amendment limits on defamation actions apply to all tort or criminal actions that attempt to prevent reputational injuries based on publication. ${ }^{320}$ If the ultimate harm flowing from the lie is damage to

\footnotetext{
317 Siegel, supra note 331, at 15 (2001) (“companies would receive compensation for the public's refusal to tolerate their potentially antisocial conduct").

318 Susie Cagle, Two Views on ag-gags: The investigator and the farm advocate, GRIST (Apr. 25, 2013), http://grist.org/food/two-views-on-ag-gags/; Debate: After Activists Covertly Expose Animal Cruelty, Should They Be Targeted With “Ag-Gag” Laws?, DemocracY Now! (Apr. 9, 2013), http://www.democracynow.org/2013/4/9/debate_after_activists_covertly_expose_animal.

319 Siegel, supra note 331, at 15; id. at 16 (noting that in the context of privacy torts - such as intrusion upon seclusion - the limits on damages are less clear, but explaining that, in part, based on the dated nature of the precedent that predates cases like Hustler); id. ("Dietemann was decided before much of the First Amendment jurisprudence related to publication damages was developed. Moreover, the question of whether publication damages should be rejected on proximate cause grounds was not raised or addressed. Thus, Dietemann did not address the principal issues currently relevant to publication damages, and its authority may reasonably be questioned on that ground alone.").

320 See, e.g., Time, Inc. v. Hill, 385 U.S. 374, 386-87 (1967); Hustler Magazine v. Falwell, 485 U.S. 46, 50-51 (1988) (holding that damages for intentional infliction of emotional distress based on publication are unavailable unless the preconditions for defamation liability, including actual malice, are satisfied). See also Sims, supra note 170, at 511 ("Food Lion argued that its
} 
reputation caused by publication of truthful information, then falsity of the publication and malice, among other things, are constitutional prerequisites for liability. ${ }^{321}$ The lies used to facilitate access to a business (the conduct of producing the undercover investigation) no less than the production of the video itself, are insulated from civil or criminal liability by the First Amendment's stringent limits on defamation. ${ }^{322}$ To hold otherwise would be inconsistent with the entire line of the Court's First Amendment defamation cases, which assume the speech is false. Indeed, it is likely that the agricultural industry's push for Ag Gag laws is a direct response to the fact that they are unable to seek relief under defamation law because the information revealed by undercover investigations is truthful.

Moreover, the Court has recognized that the publication of truthful information about a matter of public significance, even if obtained unlawfully, may still be protected by the First Amendment. In Bartnicki $v$. Vopper, ${ }^{323}$ the Court held that the media's publication of the contents of a cellphone conversation regarding a highly contentious union negotiation were protected by the First Amendment, even where the media had reason to believe that the conversation was illegally intercepted and recorded. While it did not categorically conclude that all publications of truthful information are constitutionally protected, it adhered to its practice in past cases that "if a newspaper lawfully obtains truthful information about a matter of public significance then state officials may not constitutionally punish publication of the information, absent a need . . . of the highest order." "'324

If lying is protected insofar as it does not cause cognizable injury, and if publication harms short of defamation are generally not cognizable, then lying for investigative purposes of facilitating a politically

enormous financial losses were proximately caused by the PrimeTime Live broadcast and should properly have been included in its compensatory damage award.").

${ }^{321}$ Sims, supra note 170, at 556-57 ("In Food Lion, ... injury to reputation--was an issue in the case [and] Judge Tilley therefore recognized that Food Lion's attempt to link its reputational injuries to the damages caused by the newsgathering torts without proving falsity or actual malice was, in fact, an attempt to circumvent Gertz and Sullivan.”).

322 Arlen W. Langvardt, Stopping the End-Run by Public Plaintiffs: Falwell and the Refortification of Defamation Law's Constitutional Aspects, 26 AM. Bus. L.J. 665, 666 (1989) ("Recent years have witnessed attempts by plaintiffs to make an end-run around the obstacles posed by defamation law's harm to reputation element and its constitutional aspects."); Food Lion, Inc. v. Capital Cities/ABC, Inc., 194 F.3d 505, 522 (1999) ("What Food Lion sought to do, then, was to recover defamation-type damages under non-reputational tort claims, without satisfying the stricter (First Amendment) standards of a defamation claim. We believe that such an end-run around First Amendment strictures is foreclosed by Hustler.").

323532 U.S. 514, 534 (2001).

324 Id. at 528 (quoting Smith v. Daily Mail Publ'g Co., 443 U.S. 97, 103 (1979)). 
significant investigation will generally be protected speech. The lie told by an undercover investigator - denying a desire to document food safety issues, for example - does not cause a harm other than those caused by the ultimate publication, and such injuries are not legally cognizable if the publication is non-defamatory. ${ }^{325}$

\section{CONCLUSION}

Lies play a surprisingly and historically important role in uncovering truth. Investigative deceptions are the hallmark of the muckraking tradition. Since the time of Upton Sinclair's work at a slaughterhouse, gaining access or even employment through deception, has led to landmark legislative reforms, shaped public opinion, and ignited political debate. These tactics are now routinely used by political activists as well. More recently, these efforts to produce political speech on matters of wide public concern by gaining access through lies have been the target of a rash of criminal statutes. Over the past few years, dozens of states have considered legislation that criminalizes misrepresentations used to gain access for purposes of investigations of the agricultural industry. A handful of states have actually enacted the laws, with other poised to do the same. These Ag Gag laws present a timely opportunity to consider the degree of constitutional protection for lies.

Whatever the ultimate status of lies generally under the First Amendment, investigative deceptions are high value lies, and laws regulating them should be subject to the most exacting constitutional scrutiny. For decades lies have all been clumped into a dichotomy - that is lies are either entirely unprotected, or they are a form of speech that is disfavored, but protected insofar as is necessary to avoid chilling valuable speech. By comprehensively identifying the doctrinal and historical case for recognizing distinct value in investigative deceptions, this Article destabilizes the misconception that all lies are equal. Many lies are entitled to First Amendment protection, but no lie is more valuable than the lie that enables important speech on issues of public concern. High value lies have evaded judicial attention for too long, and with the rise of Ag Gag laws their time in the First Amendment spotlight has finally arrived. As we demonstrate, in the context of lies, the First Amendment critically intersects with the law of causation, and because the harm flowing from an investigation is linked to publication or exposé and not the lie itself, investigative deceptions are entitled to strict scrutiny.

325 One could imagine that if the investigator not only lies but stages the reported conduct, then damages would exist. Cf. Brokers' Choice of Am., Inc. v. NBC Universal, Inc., 757 F.3d 1125, 1139-40 (10th Cir. 2014) (recognizing that when the "unedited footage" from an undercover investigation would show that the publication created a "false impression", then an action for defamation is colorable). 